\title{
Substrate limitations for heterotrophs: Implications for models that estimate the seasonal cycle of atmospheric $\mathrm{CO}_{2}$
}

\author{
James T. Randerson, Matthew V. Thompson, and Carolyn M. Malmstrom \\ Carnegie Institution of Washington, Department of Plant Biology, Stanford, California \\ Department of Biological Sciences, Stanford University, Stanford, California \\ Christopher B. Field \\ Carnegie Institution of Washington, Department of Plant Biology, Stanford, California
}

Inez Y. Fung

NASA Goddard Institute for Space Studies, New York

School of Earth and Ocean Sciences, University of Victoria, Victoria, British Columbia, Canada

\begin{abstract}
We examine the sensitivity of the seasonal cycle of heterotrophic respiration to model estimates of litterfall seasonality, herbivory, plant allocation, tissue chemistry, and land use. As a part of this analysis, we compare heterotrophic respiration models based solely on temperature and soil moisture controls (zero-order models) with models that depend on available substrate as well (first-order models). As indicators of regional and global $\mathrm{CO}_{2}$ exchange, we use maps of monthly global net ecosystem production, growing season net flux (GSNF), and simulated atmospheric $\mathrm{CO}_{2}$ concentrations from an atmospheric tracer transport model. In one first-order model, CASA, variations on the representation of the seasonal flow of organic matter from plants to heterotrophs can increase global GSNF as much as $60 \%\left(5.7 \mathrm{Pg} \mathrm{C} \mathrm{yr}^{-1}\right)$ above estimates obtained from a zeroorder model. Under a new first-order scheme that includes separate seasonal dynamics for leaf litterfall, fine root mortality, coarse woody debris, and herbivory, we observe an increase in GSNF of $8 \%\left(0.7 \mathrm{Pg} \mathrm{C} \mathrm{yr}^{-1}\right)$ over that predicted by the zero-order model. The increase in seasonality of $\mathrm{CO}_{2}$ exchange in first-order models reflects the dynamics of labile litter fractions; specifically, the rapid decomposition of a pulse of labile leaf and fine root litter that enters the heterotrophic community primarily from the middle to the end of the growing season shifts respiration outside the growing season. From the perspective of a first-order model, we then explore the consequences of land use change and winter temperature anomalies on the amplitude of the seasonal cycle of atmospheric $\mathrm{CO}_{2}$. Agricultural practices that accelerate decomposition may drive a long-term increase in the amplitude, independent of human impacts on plant production.

Consideration of first-order litter decomposition dynamics may also help explain year-to-year variation in the amplitude.
\end{abstract}

\section{Introduction}

Terrestrial net ecosystem production (NEP) measurements are arguably the single most important quantity for validating global-scale ecosystem models. These fluxes can be obtained experimentally at the plot scale in low-stature ecosystems using chamber measurements [e.g., Oechel et al., 1994] and at ecosystem to regional scales using eddy covariance techniques [e.g., Goulden et al., 1996]. At the global scale, atmospheric tracer transport models use spatially resolved time series of NEP as input to generate seasonal estimates of atmospheric CO2 concentrations at various stations [e.g., Denning, 1994; Heimann and Keeling, 1989; Fung et al., 1987]. Comparisons of $\mathrm{CO} 2$ concentrations predicted from tracer transport models

Copyright 1996 by the American Geophysical Union.

Paper number 96GB01981.

$0886-6236 / 96 / 96 \mathrm{~GB}-01981 \$ 12.00$ with observations from global $\mathrm{CO} 2$ sampling networks can lead to refinements in our understanding of ecosystem processes [Knorr and Heimann, 1995] and atmospheric transport [Denning et al., 1995]. These comparisons may also lead to the identification of gaps in the network of sampling stations [e.g., Fung et al., 1991]. In terms of the global carbon cycle, the interactive use of biosphere and tracer transport models can provide important constraints on the spatial and temporal nature of the 'missing' terrestrial carbon sink [e.g., Tans et al., 1990].

Most biosphere models calculate NEP as the difference between either gross primary production (GPP) and total ecosystem respiration [Gillette and Box, 1986; Raich et al., 1991; Running and Hunt, 1993; Randall et al., 1996] or net primary production (NPP) and heterotrophic respiration [Goldewijk et al., 1994; Potter et al., 1993]. In this article, we primarily consider NEP in terms of the latter formulation as we wish to examine some of the assumptions behind 
heterotrophic respiration calculations. Many of the ideas we develop, however, also will apply to the GPP formulation because in many regions heterotrophic respiration comprises a significant fraction of total ecosystem respiration.

The magnitude of the seasonal changes in NEP can be compared between regions using an index known as growing season net flux (GSNF) [Fung et al., 1983]. This quantity is defined as the integral of NEP over the course of the growing season (i.e., over the period when NPP exceeds heterotrophic respiration). Estimates of GSNF from various studies are not always strictly comparable because this quantity depends on the resolution over which it is sampled in both time and space. With this in mind, most estimates of global GSNF are between 7 and $14 \mathrm{Pg} \mathrm{C} \mathrm{yr}^{-1}$ [Denning, 1994; Fung et al., 1983; Potter et al, 1993]. In comparison, most global NPP estimates are between 45 and $70 \mathrm{Pg} \mathrm{C} \mathrm{yr}^{-1}$ [Goldewijk et al., 1994].

GSNF is roughly an order of magnitude lower than NPP because heterotrophic respiration and NPP tend to covary seasonally. Temperatures and soil water potentials that limit plant growth also tend to limit microbe-mediated decomposition within the soil. In high-latitude ecosystems, rapid temperature swings create relatively narrow windows when conditions are favorable for high metabolic rates in both plants and heterotrophs. The seasonal coupling of NPP and heterotrophic respiration has dimensions that extend beyond just favorable windows of climate; heterotrophic metabolism also depends strongly on the time at which plant substrate becomes available as a food source for the various organisms that comprise the heterotrophic community. In the case of aboveground herbivores, available substrate consists of living and recently senesced plant tissues. In the case of soil organisms (e.g., bacteria, fungi, nematodes, and arthropods) available substrate consists of organic material delivered to the soil or soil surface via herbivores, leaf litterfall, root production, root exudation, and root mortality.

To date, the treatment of heterotrophic respiration in global-scale modeling studies has been somewhat disparate. The simplest respiration models used in conjunction with atmospheric tracer transport models lump the entire heterotrophic community together with response functions for temperature and less frequently for soil moisture [e.g., Bonan, 1995; Knorr and Heimann, 1995; Randall et al., 1996; Fung et al., 1987]. Respiration estimates of this type are zero-order in the sense that they are independent of the amount of available substrate. Other models that include more sophisticated treatments of heterotrophic respiration focus almost exclusively on microbially mediated decomposition of carbon from pools of varying recalcitrance [e.g., Parton et al., 1993; Jenkinson et al., 1991]. Models of this nature are firstorder because heterotrophic respiration fluxes are linearly proportional to the size of the pool of available substrate. While first-order respiration models have a strong empirical foundation in ecosystem ecology, they have not been widely employed at the global scale to answer questions related to the seasonality of atmospheric $\mathrm{CO}_{2}$.

Does the more complex first-order formulation yield significantly different answers for questions related to seasonality of $\mathrm{CO}_{2}$ ? In particular, are first-order respiration dynamics important in the interpretation of the long-term increase and year-to-year variation of the amplitude of the seasonal cycle? Here we present results from some simple model experiments that we performed to address these questions. Specifically, we compare the differences between zero- and first-order models in terms of their estimates of the seasonal cycle of heterotrophic respiration using the framework of the Carnegie-Ames-Stanford Approach (CASA) terrestrial biosphere model [Potter et al., 1993; Field et al., 1995].

\section{Methods}

This paper is organized around five model experiments, each of which consisted of a series of runs. The experiments were designed to test the sensitivity of the seasonal cycle of heterotrophic respiration, NEP, and GSNF to (1) the seasonal flow of organic material from plants to heterotrophs, (2) estimates of aboveground herbivory, (3) plant allocation, (4) tissue chemistry of plant litter, and (5) land use change. The first four experiments focus on first-order aspects of heterotrophic respiration that we identified a priori as the most likely candidates for influencing the seasonality of heterotrophic respiration. We included the experiment on land use because agricultural activity affects many aspects of the heterotrophic community, including those examined in the first four experiments.

One of the model runs we present in the first experiment described in section 3.1 consists of a new scheme for the seasonal flow of organic matter from plants to heterotrophs that we define in Appendix A. This flow is designed to replace the litterfall algorithm in CASA described by Potter et al. [1993]. It includes herbivory and has separate seasonal dynamics for leaf litterfall, root mortality, and the seasonality of coarse woody debris. In experiments $2,3,4$, and 5 , we used this version of CASA as a template for further modification.

\subsection{Model Description}

As our focus here is on the seasonal dynamics of heterotrophic respiration, we use the same set of monthly NPP maps in every model run. In CASA, we calculate NPP for each month as the product of photosynthetically active radiation absorbed by the canopy (APAR) and a light use efficiency term. APAR is a function of satellite-derived normalized difference vegetation index (NDVI) [Los et al., 1994]. The light use efficiency term in CASA is adjusted for each location to account for temperature and moisture [Field et al., 1995]. The global annual sum of NPP for the input variables used here (Table 1) was $53.4 \mathrm{Pg} \mathrm{C} \mathrm{yr}^{-1}$.

The belowground soil organic matter submodel in CASA was modified from the original description by Potter et al. [1993] (Figure 1). The flow of carbon is essentially the same, following the structure of the Century model [Parton et al., 1993; Parton et al., 1988]. Maximum decomposition rate constants for the various litter and soil pools were taken from Parton et al. [1993]. We calculate respiration from each pool as the product of a maximum rate constant $(k)$, the carbon pool size $(C)$, unitless temperature $\left(T_{s}\right)$ and soil moisture $\left(W_{s}\right)$ scalars, and the fraction of carbon that is not assimilated into microbial biomass $(1-M)$.

$$
R(t)=\sum_{i=1}^{9} k(i) C(i, t) T_{s}(t) W_{s}(t)(1-M)
$$

The same set of monthly temperature and soil moisture scalars 
Table 1. Characteristics of the CASA Terrestrial Biosphere Model Used Here

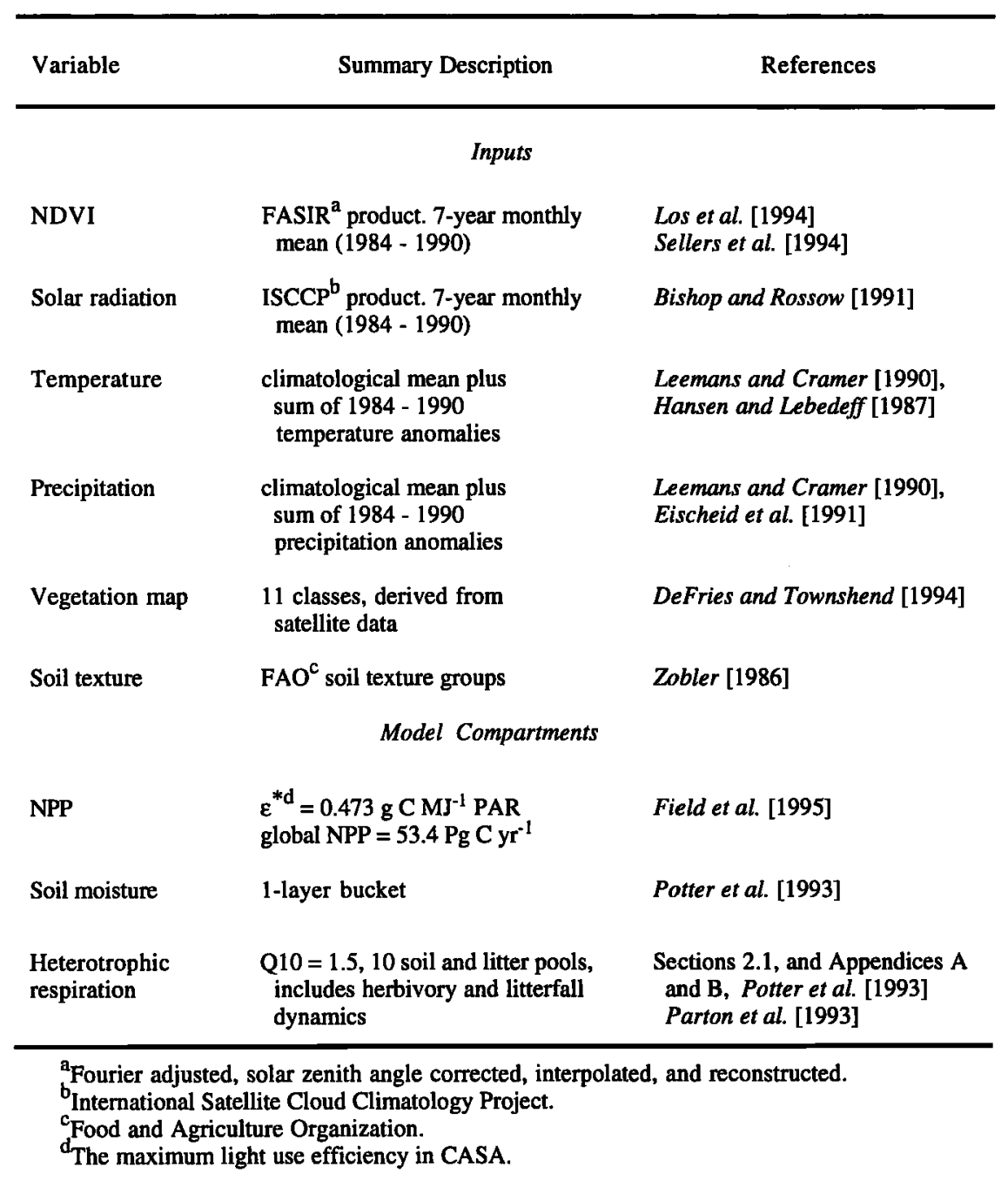

was used in every model run. A Q10 of 1.5 was used to scale the rate of microbial decomposition to surface air temperature [Raich and Potter, 1995].

$$
T_{s}(t)=\mathrm{Q} 10\left(\frac{(T(t)-35.0)}{10.0}\right)
$$

where $T(t)$ is mean monthly air temperature (in degrees Celsius). The soil moisture scalar was derived from the ratio of the sum of stored soil moisture (SM) and precipitation (PPT) to potential evapotranspiration (PET) [Parton et al., 1993].

For

$$
S(t)=\frac{\operatorname{SM}(t-1)+\operatorname{PPT}(t)}{\operatorname{PET}(t)}
$$

$$
\begin{aligned}
0.0 \leq S(t) \leq 1.0: W_{s}(t)=0.1+0.9 S(t) \\
1.0<S(t) \leq 2.0: W_{s}(t)=1.0 \\
2.0<S(t) \leq 30.0: W_{s}(t)=[1.0+(1.0 / 28.0)]- \\
(0.5 / 28.0) \mathrm{S}(\mathrm{t})
\end{aligned}
$$

$$
S(t)>30.0: W_{s}(t)=0.5
$$

The response of the soil moisture scalar to anaerobiosis (equations (4c) and (4d)) was attenuated from the function used by Potter et al. [1993] because at the $1^{\circ} \times 1^{\circ}$ grid scale, monthly soil respiration rates do not decrease in response to increases in precipitation except in wetland areas [Raich and Potter, 1995].

The split of material between metabolic and structural litter pools in CASA is set by pre-defined $C / N$ and lignin concentrations of plant tissue for each vegetation type (Appendix B). Several other studies that model decomposition at local and global scales also have used fixed ecosystem $\mathrm{C} / \mathrm{N}$ and lignin concentrations [e.g., Friedlingstein et al., 1995]. We assume that a primary effect of nutrient limitation on plant development is a reduction of plant investment in light harvesting and consequently APAR [Field et al., 1995].

For the model runs presented here, we constructed a mean biosphere year representative of 1984-1990 (Table 1). Each model run lasted for 5000 years $(60,000$ time steps) to insure steady state soil carbon pool sizes and fluxes. The one exception to this steady state rule occurred in the land use change experiment in which one of the model runs lasted for only 100 years to reflect the relatively short duration of the 


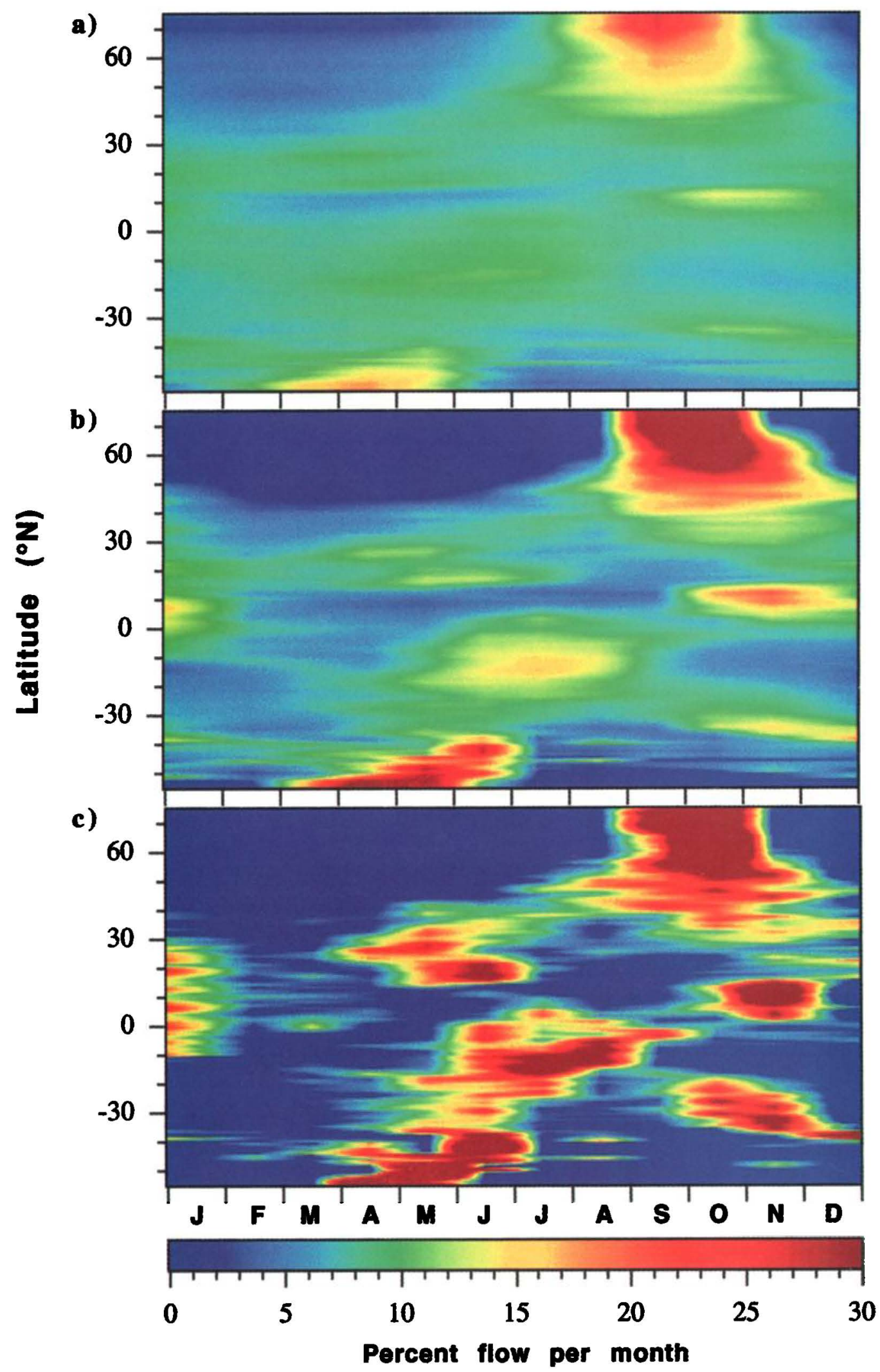

Plate 1. The percent of annual NPP transferred from plants to heterotrophs in each month as predicted by (a) the new CASA flow scheme, (b) Potter et al. [1993] algorithm, and (c) a pulse distribution during the month of greatest leaf loss. Plate 1 shows the average of terrestrial surfaces in $1^{\circ}$ latitude bands. These three distributions correspond to model runs 2, 3, and 4 of the seasonal flow of organic matter from plants to heterotrophs experiment. The distribution for model run 1 (constant fraction) is not shown because it does not vary seasonally. We do not show the distribution from model run 5 (a zero-order estimate) because this formulation of respiration does not depend on the timing of litterfall or available substrate (equation (5)). 


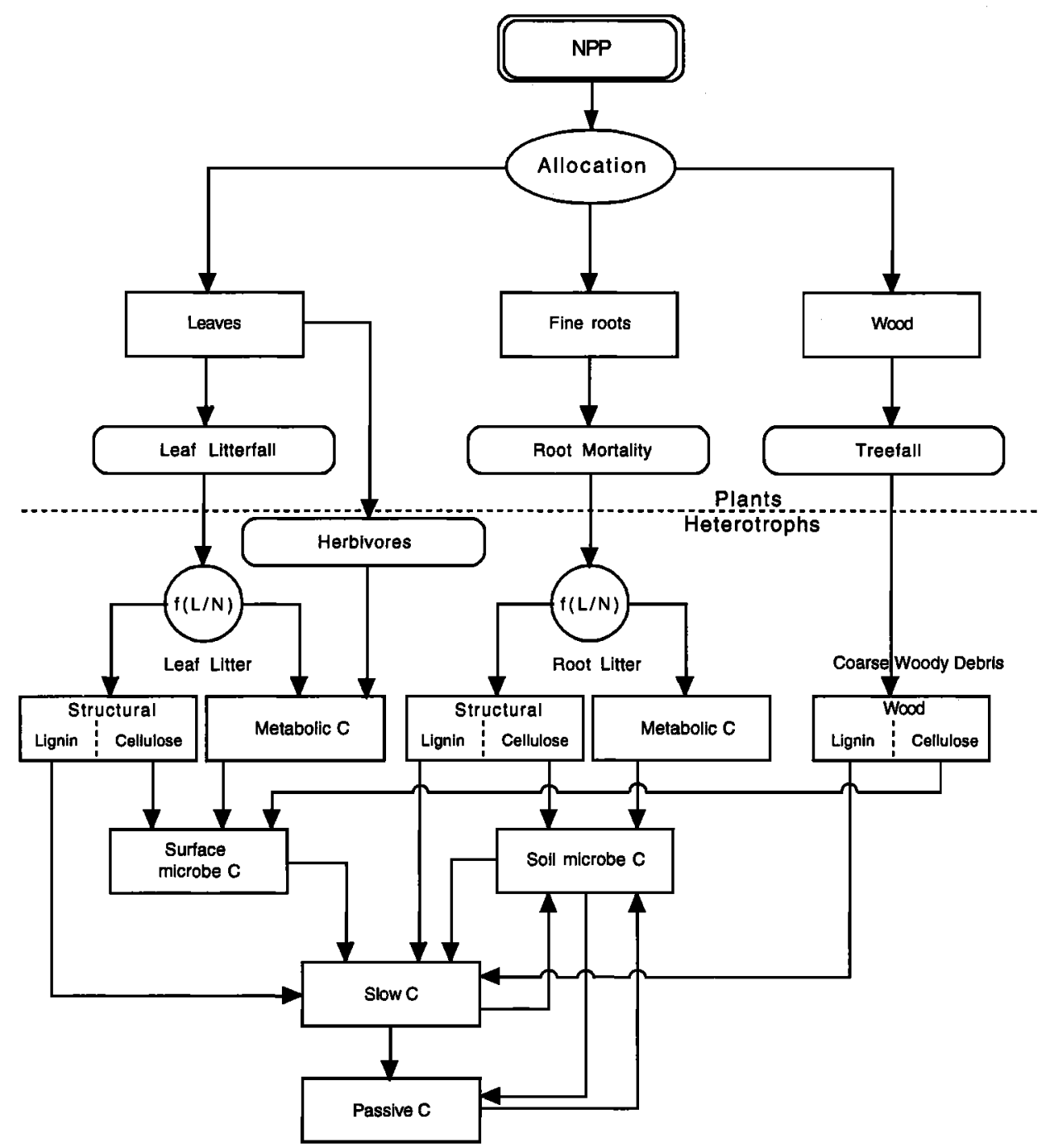

Figure 1. The structure of the Carnegie-Ames-Stanford Approach (CASA) terrestrial biosphere model with the changes described in Appendices A and B.

period of substantial human transformation of the land surface. The assumption that the biosphere is in annual steady state during the 1984-1990 period is unrealistic [Francey et al., 1995; Dai and Fung, 1993] but appropriate here where the focus is solely on the seasonal cycle.

As in previous versions of the model, a fixed litter allocation ratio of $1: 1: 1$ is used for ecosystem leaf, wood, and fine root annual litter in forests. In grasslands, tundra, and agriculture, we assume an equal split between shoots and fine roots. We investigated the sensitivity of seasonal respiration estimates to these allocation patterns in the third experiment, described in section 3.3.

\subsection{Atmospheric Tracer Transport Model}

We used the Goddard Institute for Space Studies (GISS) coarse resolution tracer transport model described by Fung et al. [1991]. The tracer model has nine vertical layers and an $8^{\circ}$ $x 10^{\circ}$ grid cell resolution. The circulation statistics of the coarse tracer model are the same as those of the $4^{\circ} \times 5^{\circ}$ model [Fung et al., 1983] from which it was derived. For each of the simulations we present, we ran the model for 3 years to achieve steady state concentrations of atmospheric $\mathrm{CO}_{2}$ at the surface. For the model runs we present here, we used only steady state terrestrial vegetation tracers consisting of NEP fields; ocean, fossil fuel, deforestation, and terrestrial sink tracers were not included.

\section{Description of Experiments}

\subsection{Seasonal Flow of Organic Matter From Plants to Heterotrophs}

This experiment consisted of four CASA model runs, each with a different seasonal flow submodel. The flow submodels were (1) a constant (aseasonal) monthly fraction, (2) a new flow scheme for CASA defined in Appendix A (Plate 1a and Figure 2), (3) the litterfall algorithm described by Potter et al. [1993] (Plate1b and Figure 2), and (4) a pulse flow in which annual NPP at each grid cell is transferred to litter pools during the month of greatest leaf area index (LAI) decrease (Plate 1c).

As a baseline for comparisons, we also performed a fifth 

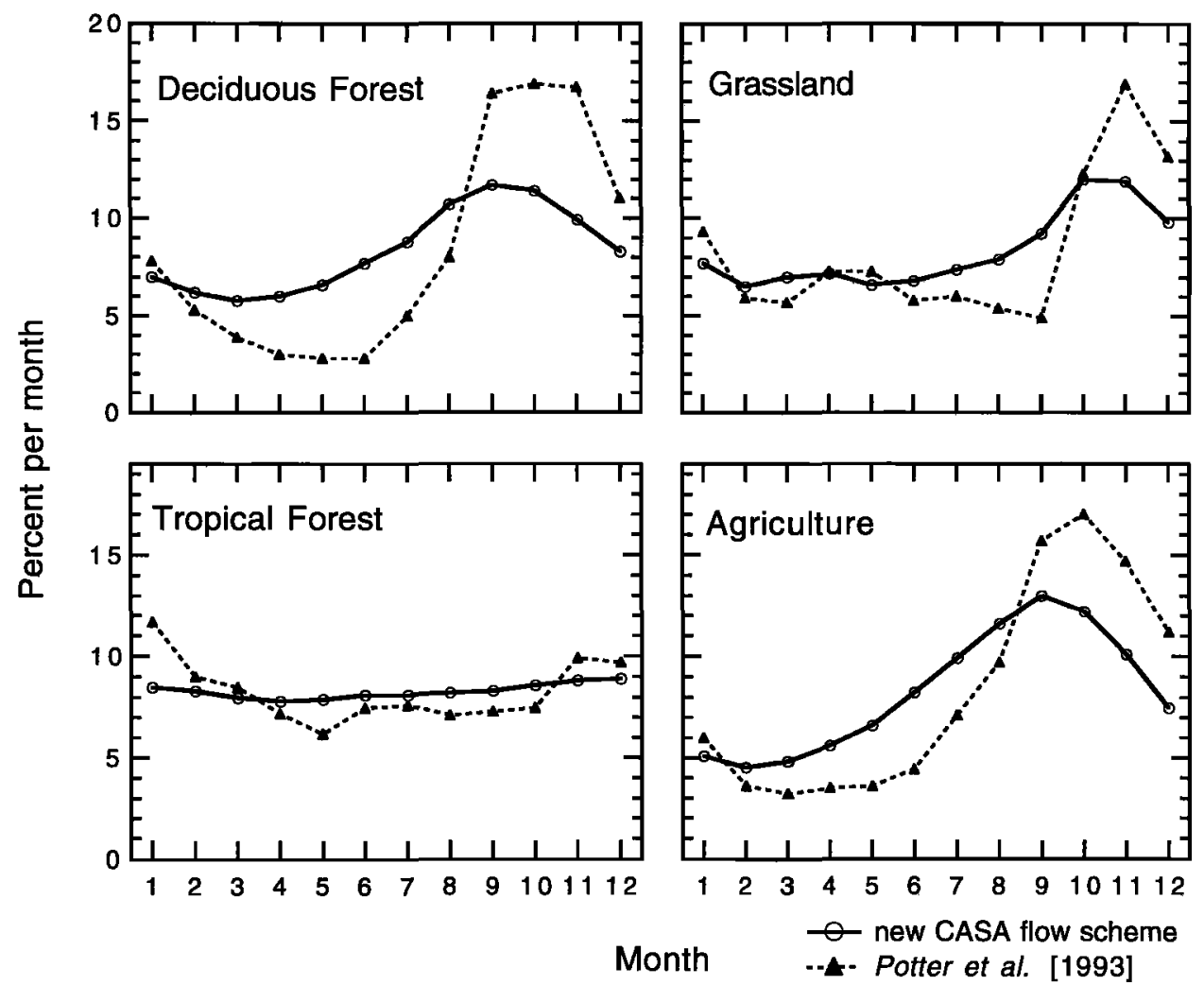

Figure 2. The percent of annual NPP transferred from plant to heterotroph pools as given by the new CASA flow scheme described in Appendix A and the Potter et al. [1993] algorithm. Mean monthly values are shown for deciduous forest, grassland, tropical forest and agriculture vegetation types in the northern hemisphere.

model run in which we estimated heterotrophic respiration using a zero-order model. The zero-order model simply redistributes total annual NPP over the course of a year according to temperature and soil moisture scalars described previously.

$$
R(t)=T_{s}(t) W_{s}(t) \frac{\sum_{t=1}^{12} \mathrm{NPP}(t)}{\sum_{t=1}^{12} T_{s}(t) W_{s}(t)}
$$

The temperature and soil moisture scalars were identical to those used in all other first-order model runs (equation (1)). Equation (5) provides a simple way to assure that the biosphere is in annual steady state.

\subsection{Herbivory}

Using the new CASA flow scheme we performed four model runs. The first model run was the control (it included herbivory as described in Appendix A). In the new CASA flow scheme, plant material excreted by herbivores is delivered directly to the metabolic surface carbon pool (Figure 1) during the following time step.

In the following model runs, we reduced herbivory everywhere by $50 \%$ from the control estimate, reduced herbivory to zero, and set herbivory to $15 \%$ of net foliar production (NFP) for all grid cells. NFP is defined as the total amount of NPP that is allocated to leaves. In CASA, material not consumed by herbivores remains in the leaf pool and is transferred to the leaf litter pools according to the leaf litterfall algorithm (equations (A2), (A3), (A4), and (A5)).

\subsection{Allocation}

In five runs, plant allocation to wood (in forest ecosystems) was set to $50 \%, 40 \%, 33 \%$ (control run), $20 \%$, and $10 \%$ of total NPP. In CASA, the fraction of production that is not allocated to woody biomass is divided evenly between leaves and fine roots.

\subsection{Litter Chemistry}

In five model runs, the lignin-to-nitrogen ratios at each grid cell were set to $200 \%, 133 \%, 100 \%$ (control run), $75 \%$, and $50 \%$ of the values prescribed in Table B1. These experiments tested the sensitivity of seasonal heterotrophic respiration estimates to the composition of leaf and fine root litter. In CASA, carbon is partitioned between the structural and metabolic litter pools according to the lignin/nitrogen ratio [Parton et al. 1993] (Figure 1).

\subsection{Land Use Change}

To investigate changes in the seasonality of heterotrophic respiration in regions affected by humans, we performed a simple experiment consisting of two model runs. In the first model run we used a "preagricultural" vegetation map in which agricultural regions (class 11) of the DeFries and Townshend [1994] map were replaced with the vegetation type (one of 
Table 2. GSNF for Model Runs in Experiments 1-4

\begin{tabular}{|c|c|c|c|c|}
\hline Experiment & Model Run & $\begin{array}{l}\text { Northern } \\
\text { Hemisphere, } \\
\mathrm{Pg} \mathrm{C} \mathrm{yr}^{-1}\end{array}$ & $\begin{array}{c}\text { Total } \\
\mathrm{Pg} \mathrm{C} \mathrm{yr}^{-1}\end{array}$ & $\begin{array}{c}\text { Percent o } \\
\text { Control }^{\mathrm{a}}\end{array}$ \\
\hline Timing & $\begin{array}{l}\text { 1, Constant flow } \\
\text { 2, New CASA flow scheme } \\
\text { 3, Potter et al. [1993] } \\
\text { 4, Pulse flow } \\
\text { 5, Zero-order (equation 5) }\end{array}$ & $\begin{array}{l}6.28 \\
6.75 \\
7.38 \\
9.19 \\
6.30\end{array}$ & $\begin{array}{c}8.91 \\
9.61 \\
10.70 \\
14.59 \\
8.89\end{array}$ & $\begin{array}{l}100 \\
108 \\
120 \\
160 \\
-\end{array}$ \\
\hline Herbivory & $\begin{array}{l}\text { 1, New CASA flow scheme } \\
\text { 2, 50\% of McNaughton et al. [1989] } \\
\text { 3, No herbivory } \\
\text { 4, Constant } 15 \% \text { herbivory all cells }\end{array}$ & $\begin{array}{l}6.75 \\
6.80 \\
6.85 \\
6.78\end{array}$ & $\begin{array}{l}9.61 \\
9.71 \\
9.82 \\
9.69\end{array}$ & $\begin{array}{l}\cdot \dot{10} \\
102.2 \\
100.8\end{array}$ \\
\hline Allocation & $\begin{array}{l}1,50 \% \text { wood } \\
2,40 \% \text { wood } \\
3,33 \% \text { wood (CASA estimate) } \\
4,20 \% \text { wood } \\
5,10 \% \text { wood }\end{array}$ & $\begin{array}{l}6.69 \\
6.72 \\
6.75 \\
6.79 \\
6.82\end{array}$ & $\begin{array}{l}9.50 \\
9.56 \\
9.61 \\
9.69 \\
9.76\end{array}$ & $\begin{array}{c}98.5 \\
99.5 \\
\bullet \\
100.8 \\
101.6\end{array}$ \\
\hline Chemistry & $\begin{array}{l}\text { 1, 200\% Table B1 C/N values } \\
\text { 2, 133\% Table B1 C/N values } \\
\text { 3, Table B1 (CASA estimate) } \\
\text { 4, 75\% Table B1 C/N values } \\
5,50 \% \text { Table B1 C/N values }\end{array}$ & $\begin{array}{l}6.61 \\
6.70 \\
6.75 \\
6.81 \\
6.88\end{array}$ & $\begin{array}{l}9.39 \\
9.53 \\
9.61 \\
9.71 \\
9.80\end{array}$ & $\begin{array}{c}97.7 \\
99.2 \\
\bullet \\
101.0 \\
101.9\end{array}$ \\
\hline
\end{tabular}

${ }^{\mathrm{a}}$ The control run in each experiment is denoted by $(\bullet)$.

classes 1-10) that was present before human disturbance. We generated this map by first identifying the corresponding potential vegetation type from Matthews [1983] for each agricultural grid cell in the DeFries and Townshend [1994] map. The Matthews [1983] vegetation type was then mapped into the most similar non-agricultural vegetation class of DeFries and Townshend [1994]. At the end of a 5000-year run, the soil pools in the preagricultural model run were at steady state.

The second model run was initialized with the steady state soil carbon pools sizes obtained from the preagricultural model run. To simulate the relatively recent major impacts of human activity, we ran the model for only 100 years using the De Fries and Townshend [1994] map, which includes agriculture. The switch to agriculture occurred instantaneously at the beginning of the model run. In CASA, grid cells identified as agricultural are characterized by low-lignin and high-nitrogen concentrations (Table B1), herbaceous cover (no allocation to woody tissue), and accelerated turnover rates of microbial, slow, and passive soil carbon pools by $25 \%$, $50 \%$, and $50 \%$, respectively, to reflect tilling and landclearing practices.

\section{Results}

At the global scale, GSNF estimates are far more sensitive to the timing of the seasonal flow of organic matter from plants to the heterotrophic community than to changes in herbivory, allocation, and tissue chemistry (Table 2). Increasing the seasonality of organic matter flow from plants to heterotrophs from a constant monthly fraction to a pulse during the month of greatest leaf loss increases global GSNF

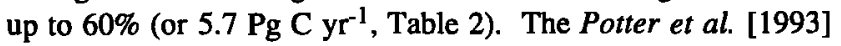

litterfall algorithm yields a $20 \%$ (or $1.8 \mathrm{Pg} \mathrm{C} \mathrm{yr}^{-1}$ ) increase in global GSNF above the zero-order model, while the new CASA

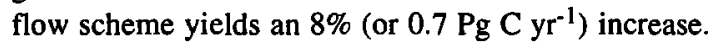

The different seasonal flow models described in experiment 3.1 converge with the zero-order model in their estimates of GSNF near the poles and substantially diverge near the equator (Figure 3a). The pulse flow model peaks near the equator with a $225 \%$ increase in GSNF above the zero-order model (off the scale in Figure 3a). Between $20^{\circ} \mathrm{N}$ and $20^{\circ} \mathrm{S}$ the Potter et al. [1993] flow model predicts a $25 \%$ or greater increase in GSNF. The constant flow model predicts only a small $(<5 \%)$ increase in GSNF at all latitudes (data not shown). The latitudinal distribution of absolute GSNF shown in Figure $3 \mathrm{~b}$ for the zeroorder model served as the baseline for comparisons shown in Figure 3a.

Figures $3 \mathrm{c}$ and $3 \mathrm{~d}$ are analogous to Figures $3 \mathrm{a}$ and $3 \mathrm{~b}$, but for the amplitude of surface $\mathrm{CO}_{2}$ concentrations derived from CASA NEP estimates coupled to the GISS tracer transport model. Increases in the amplitude of the seasonal cycle of atmospheric $\mathrm{CO}_{2}$ as predicted by the tracer transport model roughly parallel the increases in GSNF that are observed for the different flow models. The amplitudes shown are those resulting from only the CASA-based terrestrial NEP estimates used in the GISS tracer transport model. The Potter et al. [1993] flow model yields increases in the amplitude of $20 \%$ or greater from $30^{\circ} \mathrm{N}$ to the south pole. From $40^{\circ} \mathrm{N}$ to $10^{\circ} \mathrm{N}$, the new CASA flow scheme yields an increase in the amplitude greater than $10 \%$ and peaks at $15 \%$ near $30^{\circ} \mathrm{N}$. The large deviations in tropical GSNF and surface $\mathrm{CO}_{2}$ amplitude for different first-order models in Figure 3 suggest that the seasonality of heterotrophic respiration is more sensitive to the flow characterization in regions where rates of decomposition are high. 


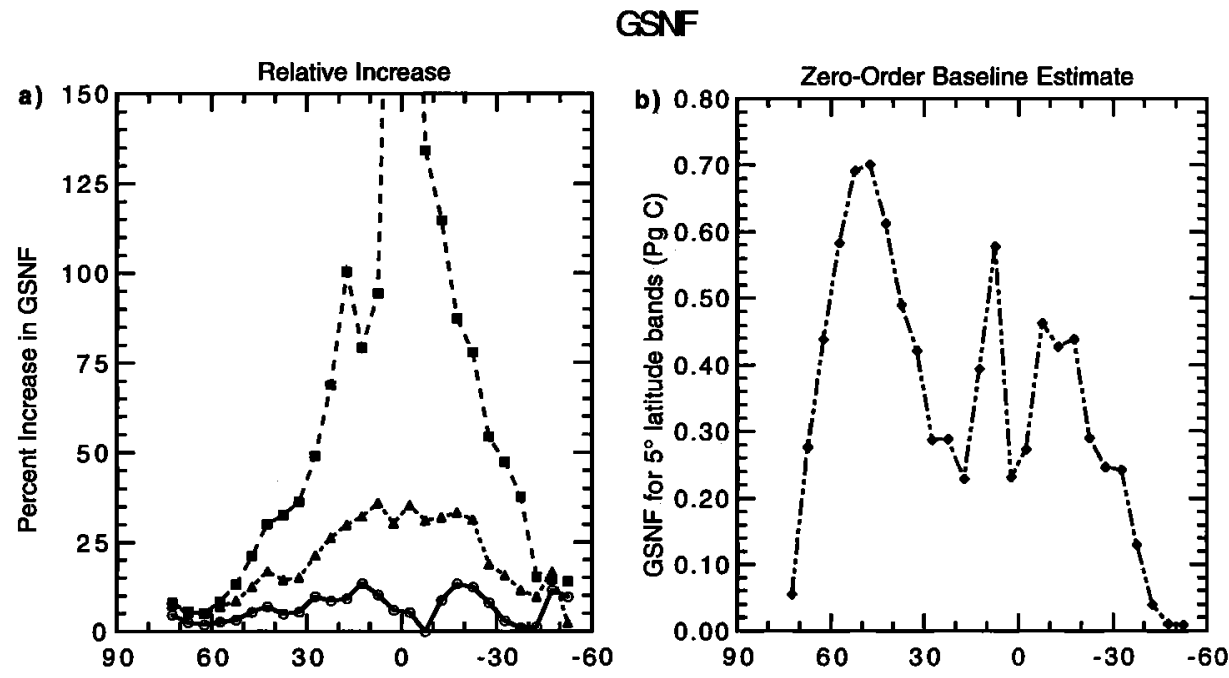

Amplitude
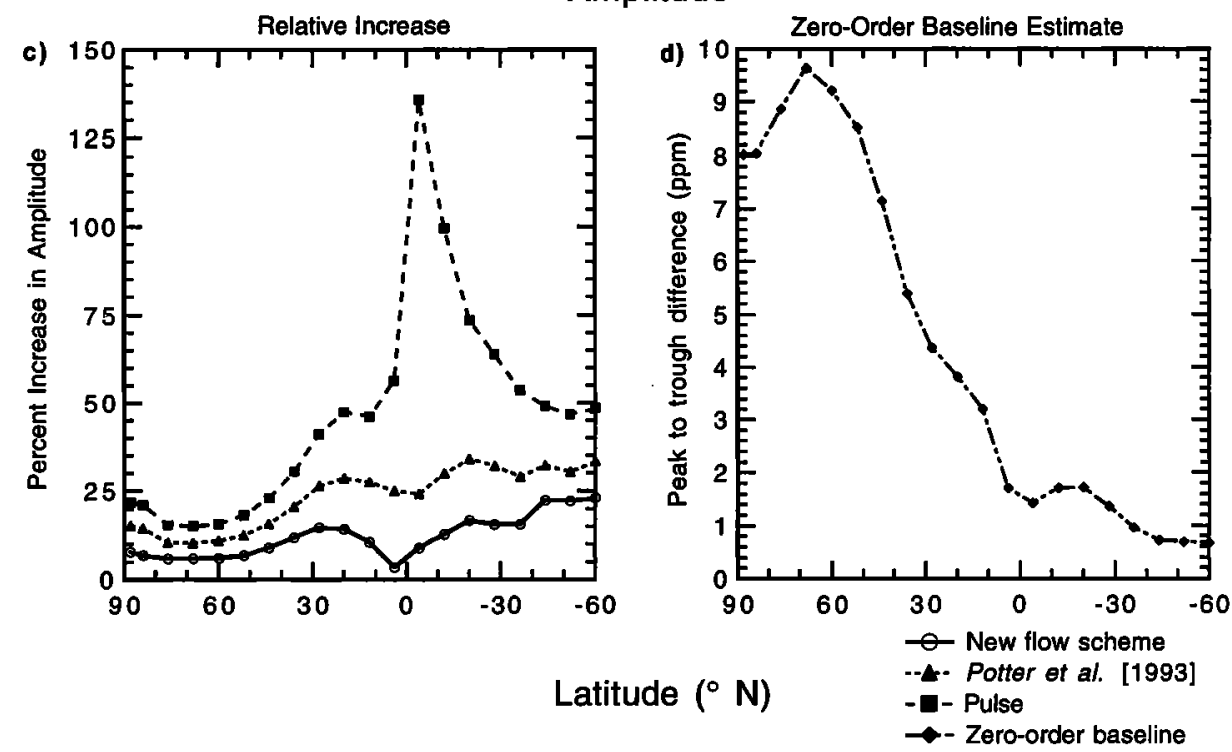

Figure 3. (a) The relative increase in GSNF for three different first-order flow models as compared with (b) a zero-order baseline estimate. Estimates are given for $5^{\circ}$ bands of latitude. (c) The relative increase in the amplitude of the seasonal cycle of atmospheric $\mathrm{CO}_{2}$ for the same set of first-order models as in Figure $3 \mathrm{a}$, as compared with (d) the zero-order model . Concentration estimates shown in Figure 3d are means for each of the $8^{\circ}$ latitude bands of the Goddard Institute for Space Studies (GISS) tracer transport model.

The amplitudes shown in Figure 3d at high latitudes in the northern hemisphere are approximately one third lower than observations of surface $\mathrm{CO}_{2}$ concentrations. A likely explanation for this damped seasonality is that the fixed planetary boundary layer height of the GISS model does not fully capture the extent of the seasonal correlation between $\mathrm{CO}_{2}$ concentration and turbulent mixing [Denning et al., 1995]. This may cause the GISS tracer transport model to underestimate the build up of surface $\mathrm{CO}_{2}$ during winter months. Alternatively, CASA NEP fluxes may be too low, perhaps because of an underestimation of NPP at high latitudes.

The estimates of global GSNF made by the constant flow model and the zero-order model do not differ substantially
(Table 2). These two approaches differ, however, in their seasonal predictions of heterotrophic respiration at the biome scale (Figure 4). The greatest deviations from the zero-order model occur in seasonal vegetation types with relatively fast turnover times of leaf and fine root litter (for example, in grasslands, agriculture, and savannas). Both the constant flow model and the new CASA flow scheme produce higher respiration estimates than the zero-order model during late winter and spring in the northern hemisphere. During late summer and early fall, the two first-order models yield lower respiration estimates than the zero-order model. The new CASA flow scheme estimates of heterotrophic respiration drop below the zero-order model estimates earlier in the year than estimates from the constant flow model (Figure 4). Many of 

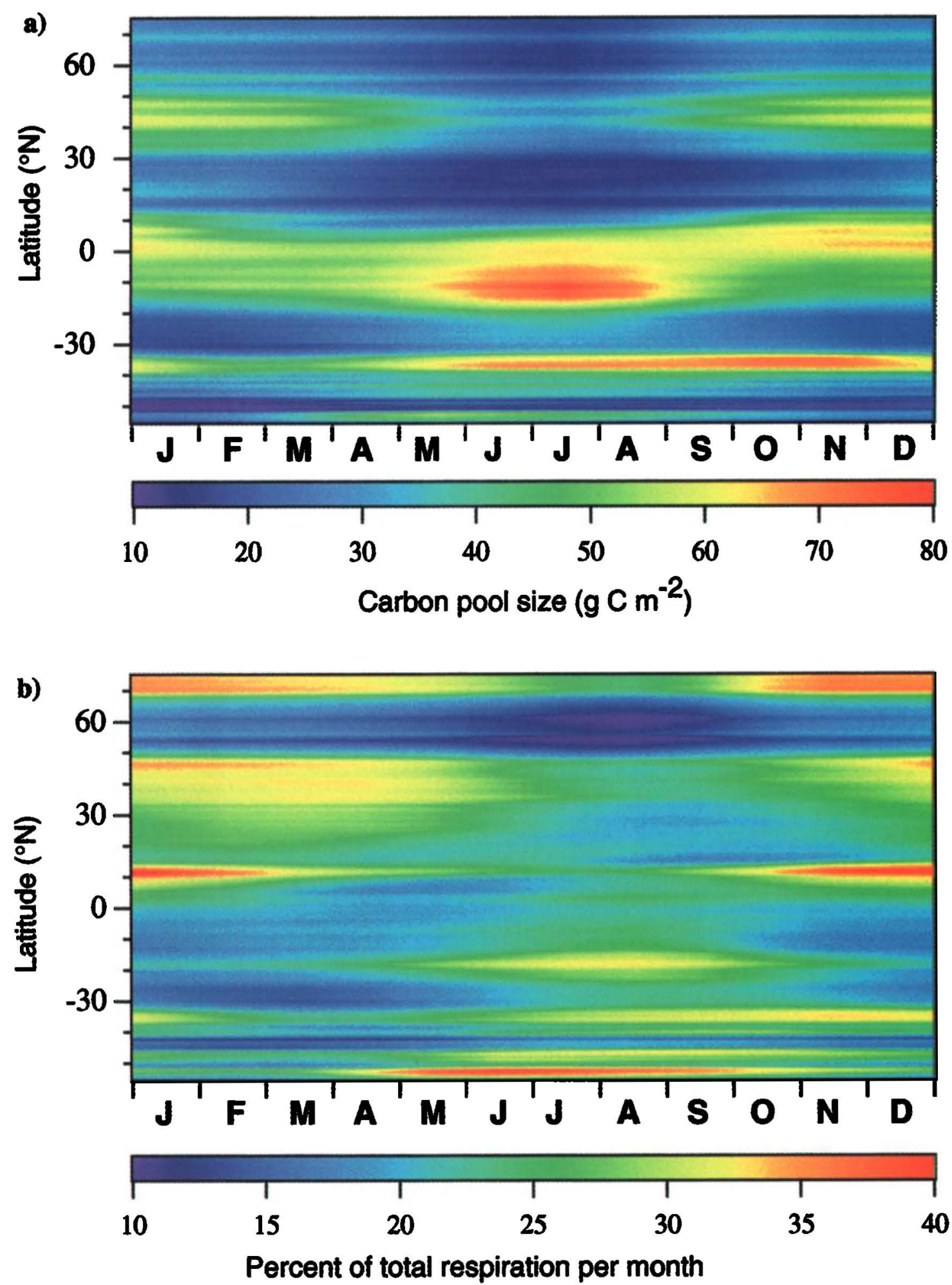

Plate 2. (a) The monthly carbon pool sizes for surface and soil metabolic litter. (b) The percent of monthly heterotrophic respiration originating from metabolic leaf and fine root litter pools for the new CASA flow scheme. In the northern hemisphere, decomposition of leaf and fine root litter comprises most of the heterotrophic respiration flux during winter and spring months because of large inputs during the fall (Platela). Most of the material in these labile litter pools decomposes relatively rapidly before the following summer. 

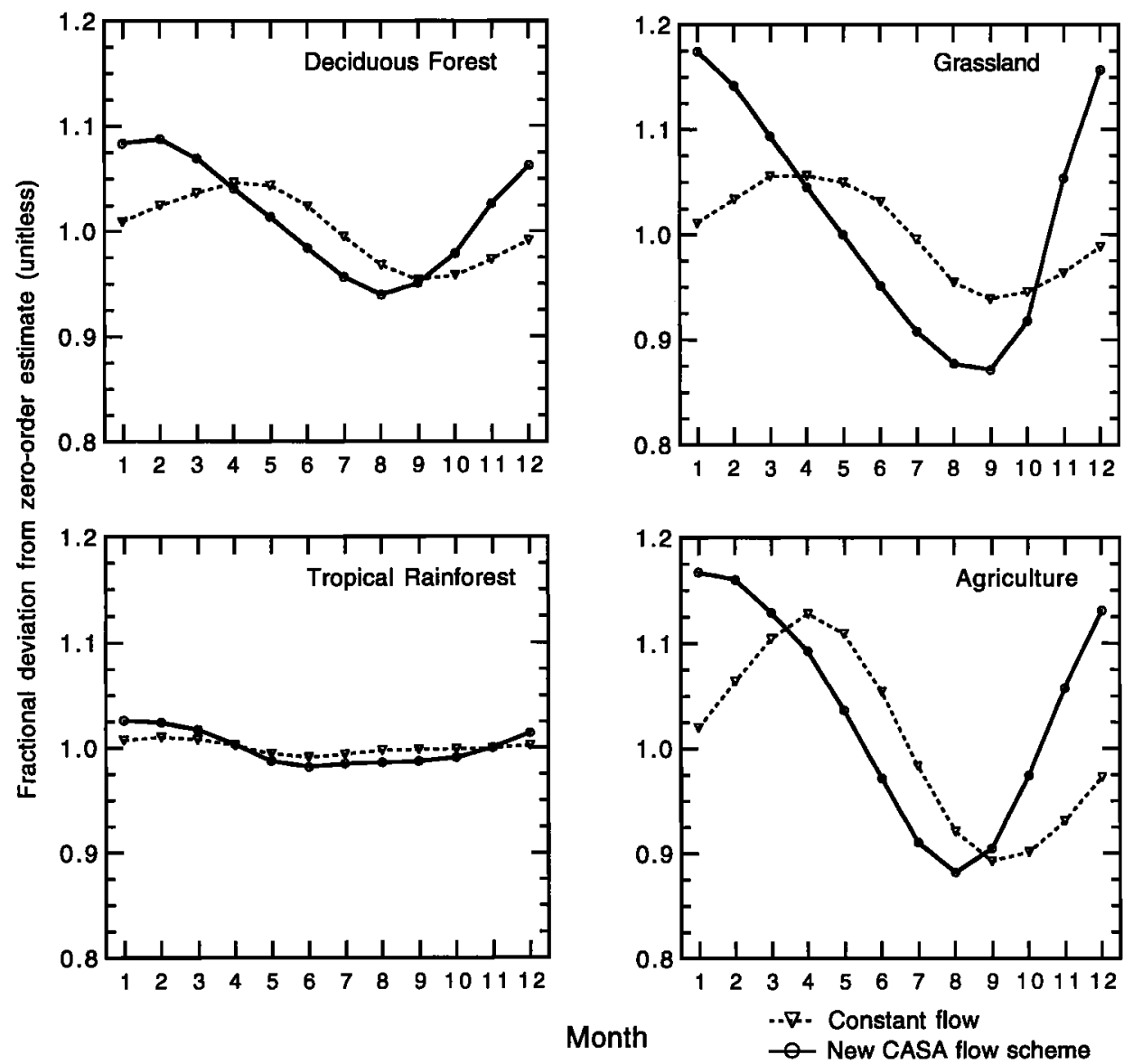

Figure 4. Monthly fractional deviations from zero-order respiration estimates (equation (5)) for the new CASA flow scheme (solid line) and the constant monthly flow (dotted line). Only grid cells in the northern hemisphere are included for each ecosystem type in order to simplify the comparisons.

the large deviations in Figure 4 occur during months when the absolute amount of heterotrophic respiration is suppressed by cold temperatures and/or dry soil. For all of the first-order models examined here, the seasonal peak of heterotrophic respiration occurs earlier in the year than the peak obtained from the zero-order model (data not shown).

In agricultural regions of the northern hemisphere, switching from a zero-order to a first-order model with potential vegetation cover increases GSNF by approximately 9\%. Including other changes that are characteristic of human disturbance increases GSNF by an additional $11 \%$ in these regions. Agricultural practices shift respiration to late fall, winter, and spring months as compared with that observed for potential vegetation in the same regions (Figure 5b). The decrease in respiration during summer months driven by human practices increases NEP and the overall seasonality of $\mathrm{CO}_{2}$ exchange in these regions (Figure $5 \mathrm{c}$ ).

Including herbivory in the new CASA flow scheme causes only a slight decrease (approximately $2 \%$ ) in total GSNF at the global scale (Table 2). The trend is consistent with greater consumption and respiration of foliar biomass by herbivores during periods of plant growth. Increasing allocation to wood and decreasing the quality of plant litter both also slightly decrease GSNF. Because these aspects of heterotrophic respiration have such a small impact on the seasonality of heterotrophic respiration in our study, we do not address them in the discussion. Instead, we focus on the mechanism by which litterfall timing affects the seasonality of heterotrophic respiration and then present several examples of when firstorder effects may be important in the interpretation of finescale features of the seasonal cycle of atmospheric $\mathrm{CO}_{2}$.

\section{Discussion}

\subsection{Why Does the Seasonality of Litterfall Affect GSNF?}

The new CASA flow scheme for the delivery of organic matter to the heterotrophic community has a distinct seasonality in areas outside of tropical forests. Both deciduous forests and agriculture in the northern hemisphere show more than a twofold difference in the seasonal flow rate of NPP from plants to heterotrophs (Figure 2). In most ecosystems, a significant fraction of leaf litterfall, root mortality, and herbaceous plant senescence occurs between the middle and the end of the growing season. At middle and high latitudes in the northern hemisphere, high flow rates during August, September, and October form a distinct pulse that is 
a)
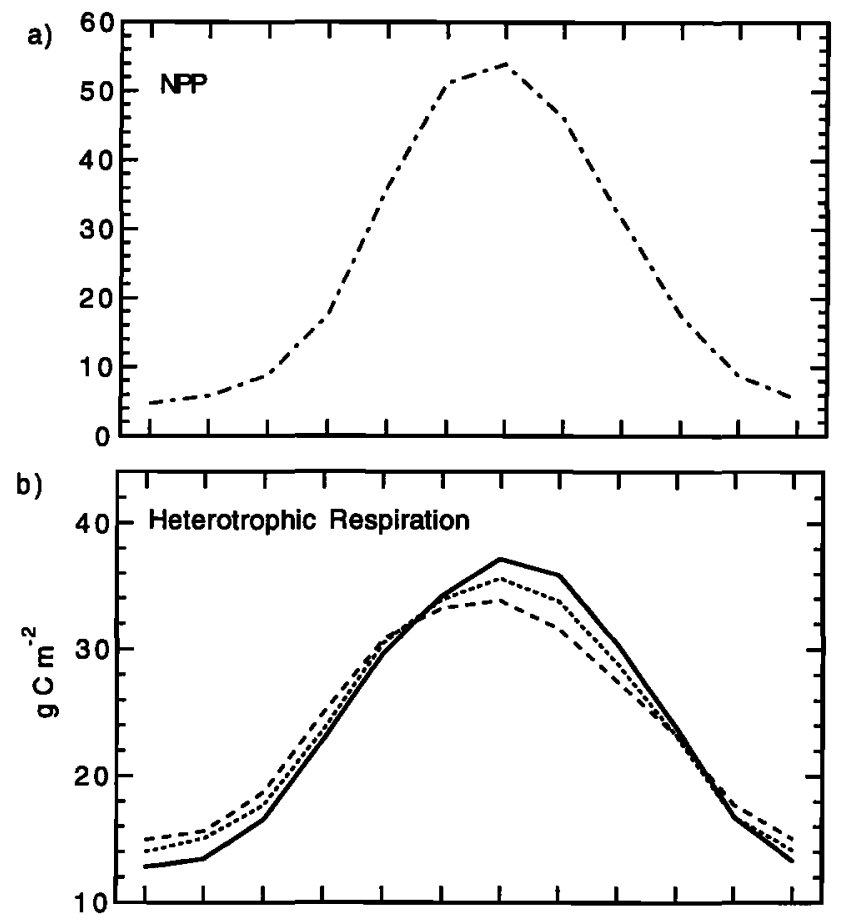

c)

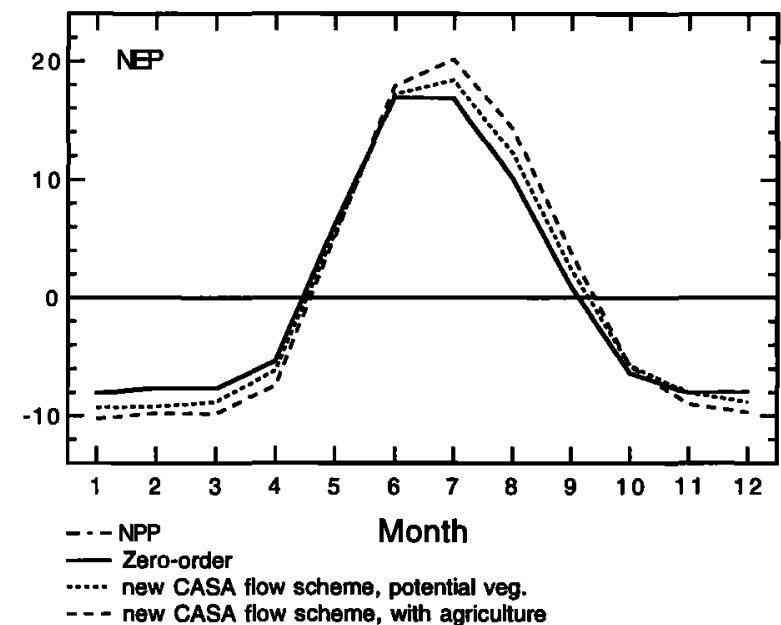

Figure 5. (a) The mean seasonal cycle of NPP for agricultural regions of the northern hemisphere. (b) The seasonal cycle of heterotrophic respiration in agricultural regions calculated according to a zero-order model, the new CASA flow scheme model with potential vegetation cover, and the new CASA flow scheme with modifications that reflect agriculture. (c) Monthly NEP for the three model runs described in Figure 5b.

visible in Plate 1a. The consequent accumulation of organic matter in metabolic leaf and fine root litter pools is evident in Plate 2a.

Except in tundra and boreal forests, the relatively labile leaf and fine root litter pools have turnover times of the order of 1 year (Table 3). Thus a large fraction of the organic material that is loaded into these rapid turnover pools at the end of the growing season decomposes before or at the onset of the following growing season. This rapid decay occurs even though total respiration may be suppressed between growing seasons by cold temperatures and/or dry soil. For example, consider a hypothetical site in which temperature and soil moisture scalars for decomposition are the same for the months of May and September, with plant growth peaking in July. From (1), if litter pools in September are twice what they are in May (because of loading from a hypothetical late season flush of leaf litterfall and root mortality), then the respiratory flux in September from these pools will be twice the flux in May.

In midlatitude cold-deciduous ecosystems in the northern hemisphere, the relative fraction of total respiration originating from leaf and fine root litter pools is high during fall, winter, and spring but then decreases in late spring and summer (Plate 2b). As the litter pools are depleted with onset of warm temperatures in the spring, microbes decomposing these tissues become substrate-limited. Here we define substrate limitation as a decrease in monthly heterotrophic respiration below that expected from a zero-order model. Following this definition, substrate limitation occurs in many ecosystems in the northern hemisphere during summer and early fall (Figure 4 and Plate 2).

In first-order ecosystem models that resolve both slow and fast soil carbon fractions, a large fraction of the annual heterotrophic respiration occurs from the decay of leaf and fine root litter. For example, in Century, approximately $80 \%$ of annual heterotrophic respiration originates from litter and microbial turnover [Schimel et al., 1994]. In the version of CASA we present here with the new flow scheme, $30 \%$ to $55 \%$ of all annual heterotrophic respiration in each grid cell originates from the decomposition of leaf and fine root litter. The CASA and Century results are consistent; in CASA, an additional $20 \%$ to $30 \%$ of total annual heterotrophic respiration comes from the turnover of the microbial biomass.

In all of the experiments here, we used the same set of maximum, nonstressed rate constants to describe the rate of mass loss from litter and soil organic matter pools. Our results are quantitatively valid only to the degree to which we have accurate turnover times for the labile litter and, in particular, for the surface and soil metabolic litter pools. Increasing decomposition rates for leaf and fine root litter pools will cause first-order models to become more sensitive to the timing of the flow of organic matter from plants to heterotrophs. In contrast, a first-order model collapses to a zero-order model in the limit as the turnover times of all respiring pools increase substantially above 1 year. The collapse occurs because large, slowly changing pools to do not fluctuate seasonally in size. This behavior explains why zero-order and first-order estimates of GSNF and the amplitude of the seasonal cycle of atmospheric $\mathrm{CO}_{2}$ converge at high latitudes (Figures 3a and 3c).

\subsection{Are the Flow Models Presented Here Realistic?}

Of the four flow models described in experiment 3.1 , two fail to capture broad ecosystem patterns in litterfall. The constant flow model does not represent the deciduous nature of cold-deciduous forests, drought-deciduous forests, and grasslands that comprise a large fraction of the total land surface. The constant flow model is useful, however, for demonstrating that litter pools and the fluxes out of them 
Table 3. Turnover Times for the Sum of Leaf and Fine Root Litter Pools

\begin{tabular}{clc}
\hline Class & \multicolumn{1}{c}{ Vegetation Type } & $\begin{array}{c}\text { Turnover Time, } \\
\text { years }\end{array}$ \\
\hline 1 & Tropical rain forests & 1.13 \\
2 & Broadleaf deciduous trees & 1.64 \\
3 & Broadleaf and needleleaf trees & 2.14 \\
4 & Needleleaf evergreen trees & 3.29 \\
5 & Needleleaf deciduous trees & 3.31 \\
6 & Savannas & 0.97 \\
7 & Perennial grasslands & 0.62 \\
8 & Broadleaf shrubs with bare soil & 1.50 \\
9 & Tundra & 3.11 \\
10 & Desert & 1.37 \\
11 & Cultivation & 1.09 \\
& Global mean & 1.60 \\
\hline
\end{tabular}

change seasonally even if NPP enters them at a constant rate. On the other extreme, the pulse flow model that distributes all annual NPP to litter pools during the month of greatest LAI decrease ascribes too much flow seasonality in ecosystems with an evergreen component. This is especially true for evergreen tropical rain forests. The constant and pulse flow models were included in our analysis because they provide lower and upper bounds on the range of expected responses for first-order models.

In contrast, the Potter et al. [1993] algorithm and the new CASA flow scheme represent more realistic flow characterizations. They both yield relatively constant flows in tropical forests and distinctly seasonal flows for deciduous forests (Figure 2). The new CASA flow scheme yields a damped seasonality as compared with the Potter et al. [1993] algorithm (Figure 2). Considered together, these two flow models describe the range of likely effects of first-order dynamics on the seasonality of heterotrophic respiration, GSNF, and the amplitude.

While the new CASA flow scheme defined in Appendix A includes a range of realistic components, its quantitative accuracy is limited by substantial deficiencies in our understanding of underlying processes. Two aspects of the flow that are especially problematic are (1) the dynamics of fine root mortality, especially in drought-deciduous forests and grasslands; and (2) the lags between leaf senescence and leaf decay.

\subsection{Land Use Change and the Amplitude of the Seasonal Cycle of Atmospheric $\mathrm{CO}_{2}$}

The amplitude of the seasonal oscillation in atmospheric $\mathrm{CO}_{2}$ is increasing. At Mauna Loa observatory, the average increase from 1958 to 1992 was approximately $0.54 \%$ per year [Keeling, 1993]. The increase has not been constant; the greatest increase occurred during the 1970s [e.g., Bacastow et al., 1985; Chan and Wong, 1990], while during the 1960s and 1980s, the amplitude showed little growth [e.g., Hall et al., 1975; Conway et al., 1994]. The increase in the seasonal amplitude suggests that human influence has led to the expansion of the biosphere by approximately $20 \%$ in the past 35 years. In fact, the most frequently invoked explanation for the increase in the amplitude is $\mathrm{CO}_{2}$ fertilization of plant growth [Bonan, 1992; Kohlmaier et al., 1989] with nutritional demands of increased growth potentially alleviated by increased nitrogen deposition [Townsend et al., 1996].

The biotic component of the increase in amplitude also can be explained in part by a seasonal decoupling of photosynthesis and respiration. The shifts in respiration observed in the land use change experiment suggest a plausible mechanism by which humans increase the amplitude of seasonal cycle of atmospheric $\mathrm{CO}_{2}$ independent of direct effects on GPP or NPP. Specifically, humans alter the seasonal cycle of heterotrophic respiration by accelerating the rate of decomposition in agricultural regions. Litter cohorts decompose more rapidly in cultivated areas with greater mass loss prior to the onset of the following growing season. The subsequent release of $\mathrm{CO}_{2}$ from litter outside of the growing season causes an increase in GSNF. Human practices that accelerate decomposition include tilling, irrigation and the replacement of forests with herbaceous crop species of a higher tissue quality. The consumption of crops by livestock and humans during periods outside of the growing season also will increase GSNF, though these processes were not considered here.

For monitoring stations that have a large agricultural footprint, shifts in respiration from agricultural regions may contribute to the long-term trend in the amplitude. For example, using the tracer transport model, we obtain an increase in the amplitude at Mauna Loa of $3.3 \%$ over the 100 years of experiment 3.5. Other midlatitude stations in the northern hemisphere show even greater increases. In lowlatitude developing countries, a large fraction of the total agricultural clearing in the past century has occurred during the period of the Mauna Loa record [e.g., Houghton, 1995]. In developed countries, the Mauna Loa record covers an intensification period during which gains from fertilizer and irrigation practices have increased crop NPP by several fold [Evans, 1980; Smil, 1990].

Of course, the seasonality and annual total of NPP is also likely to change with the intensity of human use [e.g., Vitousek et al., 1986]. Seasonal shifts in heterotrophic respiration should be considered along with changes in NPP in future, more realistic assessments of the net impact of humans on the seasonal cycle of atmospheric $\mathrm{CO}_{2}$.

\subsection{The Sensitivity of the Amplitude to Temperature Anomalies}

Keeling et al. [1996] find that the amplitude increase is significantly correlated with positive temperature anomalies. Here we consider the consequences of zero- and first-order models on the interpretation of the impact of temperature anomalies on the seasonal cycle of atmospheric $\mathrm{CO}_{2}$. As most of the warming anomalies occur during the winter and spring [Chapman and Walsh, 1993], we will specifically examine the impact of an anomaly occurring during these two seasons in the northern hemisphere in a thought experiment outlined below.

In response to a winter/spring warming anomaly, a firstorder respiration model resolving labile litter fractions will decompose a greater fraction of labile litter from the previous year before the onset of plant growth in the spring. This will 
cause $\mathrm{CO}_{2}$ concentrations in the atmosphere to peak in the spring at anomalously high values. During the summer, heterotrophic respiration fluxes will be lower than normal because the labile litter pools will have been depleted even further than usual. This will lead to greater net uptake of $\mathrm{CO}_{2}$ during the summer and an anomalously low trough in the atmosphere in the fall. In addition, nitrogen mineralized from the increased decomposition may stimulate plant growth during the summer. Thus a first-order representation of heterotrophic respiration can amplify the response of the ecosystem to winter/spring temperature anomalies by providing a mechanism for greater uptake during the following growing season. In contrast, a zero-order model of respiration will respond only during the time of the initial anomaly.

\subsection{Other Limits to our Ability to Represent the Seasonal Cycle of Heterotrophic Respiration}

Without question, soil moisture and soil temperature are the two most important controllers of the seasonal dynamics of heterotrophic respiration [Raich and Schlesinger, 1992; Raich and Potter, 1995]. These two variables are difficult to estimate as they strongly depend on canopy thickness, topography, soil texture, snow cover, and the insulating properties of surface litter and moss. Improvements in our ability to predict soil moisture and soil temperature at regional to global scales are perhaps the most important prerequisite to more accurate estimates of the seasonal cycle of heterotrophic respiration.

In addition, there is considerable uncertainty in the way these variables relate to respiratory fluxes. There is not, for example, a consensus on whether the temperature sensitivity of microbial respiration depends on ecosystem type or climate. Recent evidence suggests that decomposition of soil organic matter is more sensitive to temperature changes (has a higher Q10) in colder regions than in warmer regions [Kirschbaum, 1995]. Most global scale ecosystem models, in contrast, use a constant $\mathrm{Q} 10$ across all ecosystems. The use of a constant Q10 reflects the commonly held belief that microbial communities are functionally interchangeable.

\section{Conclusions}

Are first-order dynamics important for questions related to the seasonality of atmospheric $\mathrm{CO}_{2}$ concentrations? In terms of the mean seasonal cycle, a realistic description of the seasonal flow of NPP from plants to heterotrophs boosts the seasonality of NEP fluxes by approximately $10 \%$ above estimates from a zero-order model at the global scale. Results from the atmospheric tracer transport model suggest that the increased seasonality in NEP fluxes translates into $5 \%$ to $20 \%$ increases in predicted amplitudes at observation stations. At local and regional scales, first-order and zero-order models may deviate even more in their estimates of $\mathrm{CO}_{2}$ fluxes, especially for ecosystems that have seasonal patterns of litterfall and high rates of litter decomposition.

As compared with other limitations in our ability to represent the mean seasonal cycle, first-order dynamics are significant but not dominant. For example, improper consideration of the seasonality of plant growth and autotrophic respiration may substantially alter monthly NPP (and NEP) estimates that are based on simple light use efficiency models. The uncertainties associated with NPP calculations are at least as great as the differences observed here between zero- and first-order heterotrophic respiration models.

First-order dynamics are likely to be more important in our interpretation of fine-scale features of the seasonal cycle. For example, zero-order models will not capture the shifts in the seasonality of heterotrophic respiration that occur during changes in land use. In addition, first-order models can either amplify or suppress seasonal ecosystem responses to climate anomalies, whereas zero-order models can not. On the timescale of decades, first-order dynamics provide an important link between present-day respiration fluxes and the past history of plant growth.

\section{Appendix A: The New CASA Flow Scheme}

In the Potter et al. [1993] version of CASA, organic matter from plants was synchronously delivered to the leaf litter, fine root litter, and coarse woody debris pools each month according to a single "litterfall" algorithm [Potter et al., 1993 (equations 14a, 14b and 14c)]. This was a first attempt to use satellite derived vegetation indices to determine the seasonal timing of litterfall and thus the time at which plant detritus becomes available to decomposers. Because leaf litterfall, fine root mortality and coarse woody debris have significantly different seasonal dynamics; we treat each of these processes separately in the new CASA flow scheme (Figure 1). We also add a new pool to the heterotrophic respiration compartment of the model to represent herbivory.

\section{A.1. Leaf Litterfall}

The algorithm for leaf litterfall dynamics depends on satellite-derived changes in LAI [Sellers et al., 1994]. It has the same functional form as the algorithm used to represent the flow of all organic matter from plants to decomposers in the work of Potter et al. [1993]. Here we calculate changes in LAI over a broader time window than in the work of Potter et al. [1993], both to provide a buffer that reflects the lag time between leaf senescence and leaf fall and also to reduce contamination from high-frequency noise in the satellite data. An alternative modeling approach that captures this lag is to represent senesced plant material as a pool with a relatively fast turnover time [Parton et al., 1988]

There are two components to the leaf litterfall algorithm representing evergreen and deciduous fractions of each grid cell.

$$
\mathbf{L T f a l l}=\mathrm{NPP}_{\text {annual }}\left[\mathrm{LT}_{\text {con }} \cdot \Delta t+\mathrm{LT}_{\mathrm{var}}(t)\right]
$$

where $\Delta t$ is the length of the model time step in years. The evergreen fraction ( $\mathrm{LT}_{\text {con }}$ ) is the ratio of the seasonal minimum of leaf area $\left(\mathrm{LAI}_{\min }\right)$ to the annual average leaf area $\left(\mathrm{LAI}_{\text {ave }}\right)$.

$$
\mathrm{LT}_{\text {con }}=\frac{\mathrm{LAI}_{\min }}{\mathrm{LAI}_{\text {ave }}}
$$

$\mathbf{L T}$ con provides a rough index of the fraction of evergreen leaf area present within a grid cell. We expect this index to identify the evergreen fraction of cover in ecosystems that experience sustained periods of environmental stress during which only the evergreen species retain their leaves. For the 
evergreen fraction of each cell, we assume that leaf litterfall is evenly distributed throughout the year.

The variable leaf litterfall fraction ( $\mathrm{LT}_{\mathrm{var}}$ ) is distributed seasonally according to negative increments in LAI.

$$
\operatorname{LT}_{\mathrm{var}}(t)=\frac{\mathrm{LL}(t)}{\sum_{t=1}^{12} \mathrm{LL}(t)}\left(1-\mathrm{LT}_{\mathrm{con}}\right)
$$

where

$$
\begin{aligned}
\mathrm{LL}(t)= & {[0.5 \cdot \mathrm{LAI}(t-2)+\mathrm{LAI}(t-1)]-} \\
& {[\mathrm{LAI}(t+1)+0.5 \cdot \mathrm{LAI}(t+2)] }
\end{aligned}
$$

leaf loss (LL) is not allowed to go below zero. Thus we partition deciduous leaf litterfall only among months when there is a net loss of leaf area. As the leaf litterfall algorithm described here is based on NDVI, we expect its accuracy to be limited by cloud contamination in the tropics and low solar zenith angles during winter months at high latitudes [e.g., Goward et al., 1991].

\section{A.2. Root Mortality and Exudation}

The seasonal dynamics of fine root mortality are difficult to quantify experimentally because root production, mortality, and decomposition occur simultaneously. The use of minirhizotrons provides new insight into fine root dynamics by allowing researchers to track cohorts of roots nondestructively. Recent studies of seasonal fine root dynamics suggest several trends that are useful for constraining the seasonality of fine root mortality.

First, in annual systems, most root mortality occurs between the middle and the end of the growing season. For example, root death rates in sorghum increase at the onset of reproductive growth and peak at flowering [Cheng et al., 1990]. Huck et al. [1987] provide further evidence that the pattern described above for sorghum is consistent with observations of other annual crop species.

In northern midlatitude forests, both root production and mortality appear to be substantially suppressed during winter months. At two sugar maple sites in Michigan, for example, more than $65 \%$ and $75 \%$ of root mortality occurs between April and October [Hendrick and Pregitzer, 1993a]. The peak mortality rates in August and September are approximately 3 times the mean rates observed during the winter. In a study of individual root cohorts at the same Michigan sites, low winter mortality rates were also observed [Hendrick and Pregitzer, 1993b]. Fahey and Hughes [1994] followed three June cohorts of roots from another northern hardwood forest during 1990, 1991, and 1992. For these 3 years, they observed that $50 \%$, $38 \%$, and $44 \%$ of the root cohorts die before October. Mortality between October and the following "late spring/early summer" only accounts for an additional $22 \%$, $26 \%$, and $11 \%$.

In CASA, we derive root mortality from leaf area and leaf loss. We choose leaf area because it integrates many of the controllers of plant growth. When leaf area is high, a developed and active root system is required to support the transpirational and nutritional requirements of the canopy. Maintenance respiration costs are likely to be much higher for fine roots during the growing season because of higher soil temperatures [Amthor, 1984; Hendrick and Pregitzer, 1993b]. Empirically, LAI is high during times when minirhizotron observations show high root mortality rates. From a practical perspective, leaf area and leaf loss can be obtained from satellite data at appropriate temporal and spatial scales for global coverage. The seasonal dependence of root mortality on LAI ( $\left.\mathrm{LAI}_{\text {factor }}\right)$ is given by the following equation:

$$
\operatorname{LAI}_{\text {factor }}(t)=\frac{\operatorname{LAI}(t)}{\operatorname{LAI}_{\text {max }}}
$$

where $\mathrm{LAI}_{\max }$ is the maximum monthly LAI for the entire year. We also include a dependence on negative changes in LAI (LL factor).

$$
\mathrm{LL}_{\text {factor }}(t)=\frac{\mathrm{LL}(t)}{\mathrm{LL}_{\max }}
$$

where $L L$ is calculated from (A4) and $L L_{\max }$ is the maximum monthly leaf loss for the year. For annual species, the leaf loss factor will capture plant senescence and thus appropriately reflect root death. In deciduous systems, including a dependence on leaf loss will shift the peak of root mortality toward the end of the growing season, which is consistent with observations in cold-deciduous forests. Much less is known about root dynamics in drought-deciduous forests. The leaf area and leaf loss factors are combined in (A7). A minimum threshold $(B=1 / 3)$ is applied to root mortality to properly represent the low, but significant, mortality rates observed during winter months in colddeciduous forests at midlatitudes.

$$
\mathrm{RT}_{\text {mort }}(t)=A \cdot \frac{\mathrm{LAI}_{\text {factor }}(t)+\mathrm{LL}_{\text {factor }}(t)}{\sum_{t=1}^{12}\left[\mathrm{LAI}_{\text {factor }}(t)+\mathrm{LL}_{\text {factor }}(t)\right]}+B
$$

The slope and intercept terms may be adjusted in the future to reflect the annual and deciduous fractions of land cover in different regions and also the severity of conditions in the soil outside the growing season.

\section{A.3. Seasonality of Coarse Woody Debris}

Factors that control tree mortality and the delivery of coarse woody debris to the forest floor include wind, fire, insect infestations, disease, snow, and floods [Harmon et al., 1986]. While several studies do suggest seasonality in the formation

Table A1. Percent Aboveground Net Foliar Production (NFP) Consumed by Herbivores

\begin{tabular}{clr}
\hline Class & \multicolumn{1}{c}{ Vegetation Type } & Consumption, \% \\
& & \\
\hline 1 & Tropical rain forests & 40.6 \\
2 & Broadleaf deciduous trees & 13.4 \\
3 & Broadleaf and needleleaf trees & 13.7 \\
4 & Needleleaf evergreen trees & 6.8 \\
5 & Needleleaf deciduous trees & 6.8 \\
6 & Savannas & 35.0 \\
7 & Perennial grasslands & 10.9 \\
8 & Broadleaf shrubs with bare soil & 2.2 \\
9 & Tundra & 3.1 \\
10 & Desert & 1.1 \\
11 & Cultivation & 14.0 \\
& Global mean (weighted by area) & 15.7 \\
\hline
\end{tabular}


of coarse woody debris, the causal agents appear to vary from region to region [Harmon et al., 1986]. Data that would be useful starting points for constructing a model of the dynamics of coarse woody debris, such as storm frequency and wind intensity, are not yet available as global-scale time series. Here we simply assume that the sum of these processes integrate at the coarse spatial scale of our model to yield a constant seasonal input to the forest floor. The actual timing of treefall is less critical than that of leaf litterfall and fine root mortality in terms of seasonal substrate limitations for heterotrophs because wood decomposes relatively slowly, and thus its mass on the forest floor remains relatively constant through the year.

\section{A.4. Herbivory}

To date, most terrestrial biosphere models ignore effects by herbivores over ecosystem processes. Because herbivores consume a large fraction of aboveground NPP in many temperate and tropical grassland ecosystems, they represent a significant pathway for the transfer of organic material from plants to decomposers [Detling, 1988; LaMotte and Bourliere, 1983]. In this section, we consider only the dynamics of aboveground herbivory. Given the paucity of belowground herbivory observations, we assume that belowground herbivory has the same seasonality as root mortality described above. For aboveground herbivory, there are three main features we wish to capture.

The spatial distribution of annual aboveground NPP consumed by herbivores is characterized with an empirical equation developed by McNaughton et al. [1989], which relates leaf material consumed by herbivores (HC) to net foliar production (NFP)

$$
\log _{10} \mathrm{HC}=2.04\left(\log _{10} \mathrm{NFP}\right)-4.80
$$

where $\mathrm{HC}$ and NFP are expressed in units of $\mathrm{KJ} \mathrm{m}^{-2} \mathrm{yr}^{-1}$. Equation (A8) was developed from a compilation of 69 herbivory observations across nine different ecosystem types. In CASA, we calculated NFP as the product of NPP and the allocation coefficient for leaves at each grid cell. From (A8), herbivore consumption increases in a parabolic fashion with NFP. McNaughton et al. [1991] argue that patterns in herbivory across ecosystems are inconsistent with a globally constant fraction of primary production entrained into higher tropic levels. Rather, in ecosystems with short growing seasons and low NPP, total herbivore consumption is limited by survival during unfavorable periods outside the growing season. Equation (A8) also is compatible with predictions from the resource availability model of plant antiherbivore defenses, which holds that plant defenses against herbivory increase as plant potential growth rates decrease [Coley et al., $1985]$.

The implementation of the McNaughton et al. [1989] relation in our model yields low consumption rates in tundra ecosystems and deserts and relatively high rates in savannas and tropical forests (Table A1). The predictions for tropical forests $(40 \%)$ are high compared with observed insect defoliation rates in rain forests [Landsberg and Ohmart, 1989].

Second, we represent seasonal $\mathrm{CO}_{2}$ releases and chemical

Table B1. Leaf Litter $\mathrm{C} / \mathrm{N}$ and Lignin Concentrations

\begin{tabular}{|c|c|c|c|c|c|}
\hline Class & Vegetation Type & $\mathrm{C} / \mathbb{N}^{\mathrm{a}}$ & References & $\underset{\%}{\text { Lignin }^{b}}$ & References \\
\hline 1 & Tropical rain forests & 40 & $\begin{array}{l}\text { [Medina and Cuevas, } 1989 ; \\
\text { Scott et al., 1992; Vitousek, } \\
\text { 1984] }\end{array}$ & 20 & $\begin{array}{l}\text { [Cuevas and Medina, 1988; Palm } \\
\text { and Sanchez, 1990; Vitousek et } \\
\text { al., 1994] }\end{array}$ \\
\hline 2 & Broadleaf deciduous trees & 50 & $\begin{array}{l}\text { [Aber and Melillo, } 1980 \\
\text { Melillo et al., 1982; Stump and } \\
\text { Binkley, 1993] }\end{array}$ & 20 & $\begin{array}{l}\text { [Geng et al., 1993; Melillo et al., } \\
\text { 1982; Stump and Binkley, 1993] }\end{array}$ \\
\hline 3 & Broadleaf and needleleaf trees & 65 & See footnote $c$. & 22 & See footnote $c$. \\
\hline 4 & Needleleaf evergreen trees & 80 & $\begin{array}{l}\text { [Geng et al., 1993; Hart and } \\
\text { Firestone, 1992; Stump and } \\
\text { Binkley, 1993; Taylor et al., } \\
\text { 1991] }\end{array}$ & 25 & $\begin{array}{l}\text { [Geng et al., 1993; Gholz et al., } \\
\text { 1985; Hart and Firestone, 1992; } \\
\text { Stump and Binkley, 1993; Taylor } \\
\text { et al, } 1991]\end{array}$ \\
\hline 5 & Needleleaf deciduous trees & 50 & [Gower and Son, 1992] & 20 & [Gower and Son, 1992] \\
\hline 6 & Savannas & 50 & $\begin{array}{l}\text { [Frost, 1984; Morris et al., } \\
\text { 1982] }\end{array}$ & 15 & [Frost, 1984] \\
\hline 7 & Perennial grasslands & 50 & $\begin{array}{l}\text { [Seastedt, 1988; Seastedt et al., } \\
\text { 1992] }\end{array}$ & 10 & [Seastedt et al., 1992] \\
\hline 8 & Broadleaf shrubs with bare soil & 65 & $\begin{array}{l}\text { [Gallardo and Merino, 1993; } \\
\text { Schlesinger, 1985] }\end{array}$ & 20 & [Schlesinger, 1985] \\
\hline 9 & Tundra & 50 & & 15 & [Chapin et al., 1986] \\
\hline 10 & Desert & 50 & $\begin{array}{l}\text { Schaefer et al., 1985; } \\
\text { Stienberger and Whitford, } \\
\text { 1988] }\end{array}$ & 15 & $\begin{array}{l}\text { [Schaefer et al., 1985; } \\
\text { Stienberger and Whitford, 1988] }\end{array}$ \\
\hline 11 & Cultivation & 40 & $\begin{array}{l}\text { [Buchanan and King, 1993; } \\
\text { Parmelee et al., 1989; Wagger, } \\
\text { 1989] }\end{array}$ & 10 & $\begin{array}{l}\text { [Buchanan and King, 1993; } \\
\text { Wagger, 1989] }\end{array}$ \\
\hline
\end{tabular}

\footnotetext{
${ }^{a}$ Unless explicitly given, dry biomass was assumed to consist of $50 \%$ carbon.

b Percent lignin is with respect to dry weight biomass.

${ }^{c} \mathrm{C} / \mathrm{N}$ and percent of lignin values for class 3 are the average of 2 and 4 .
} 
transformations of plant material mediated by herbivores by assuming that on a monthly time step all plant material consumed by herbivores is either assimilated or excreted. This is in agreement with typical rates of passage of organic matter through the digestive track of ungulates that range from 12 to 140 hours [van Hoven and Boomker, 1985]. Among herbivores, mammals and invertebrates have substantially different assimilation efficiencies. Invertebrates tend to have lower assimilation efficiencies than mammals [LaMotte and Bourliere, 1983]. Mammals, however, respire most of the assimilated energy because of their fast homeothermic metabolism, whereas invertebrates use a larger fraction for growth and reproduction. Here we represent all herbivores with one compartment per grid cell. For this compartment, we chose a global assimilation efficiency of 0.6 to crudely represent a community of vertebrate and invertebrate herbivores.

As herbivore biomass is typically 2 orders of magnitude less than the sum of annual consumption, we assume that all the assimilated plant material is released as $\mathrm{CO}_{2}$ each month. Nonassimilated (excreted) material is transferred to the litter metabolic pool, which has relatively fast turnover times and low $\mathrm{C} / \mathrm{N}$ ratios.

We represent the seasonal dynamics of herbivore consumption (SC) as a linear function of monthly NPP.

$$
\mathrm{SC}(t)=A \cdot \frac{\mathrm{NPP}(t)}{\sum_{t=1}^{12} \mathrm{NPP}(t)} \cdot \mathrm{HC}+B
$$

where $\mathrm{HC}$ is consumption from (A9), $A$ is equal to $2 / 3$ and $B$ is equal to $1 / 3$. The nonzero intercept term was included to provide a minimum consumption limit outside the growing season.

\section{Appendix B: Tissue Chemistry for Litter by Vegetation Type}

Initial leaf litter $\mathrm{C} / \mathrm{N}$ and lignin concentrations used in the model runs are representative of the references cited in Table B1 and are similar to those listed in Table 1 of Friedlingstein et al. [1995]. Conifer forests (class 4) have the most recalcitrant litter, while agricultural areas (class 11) have the highest quality litter. Tropical forests have the highest quality (lowest $\mathrm{C} / \mathrm{N}$ and lignin concentrations) leaf litter of all forest types. Twigs, branches, and fruit are classified as woody litter.

Tissue chemistry data for fine roots is relatively sparse. Values from studies that report both lignin and $\mathrm{C} / \mathrm{N}$ ratios are widely scattered. Here we use the same $\mathrm{C} / \mathrm{N}$ and lignin concentrations for fine roots as we do for leaves. In forest ecosystems, the initial lignin concentration of wood was set to $30 \%$ [Harmon et al., 1986 Table 2]. The maximum rate constant for wood decomposition was set to 0.02 per month. We chose this maximum monthly rate constant to reproduce annual decay rates in temperate forests of approximately 0.10 per year following from Table 3 of Harmon et al. [1986].

Acknowledgments. This research was funded in part by an NASA EOS/IDS grant to P. J. Sellers and H. A. Mooney and a DOE WESTGEC Grant to C. B. F. and J. A. Berry. J.T.R is supported on a NASA Earth System Science Fellowship. C.M.M. is supported on a
DOE Global Change Fellowship. The complete model (in C with Unix C shell scripts and with documentation) is available upon request. We thank Peter Vitousek, Anne Ruimy and Geeske Joel for useful discussions and comments on the manuscript and Jasmin John for help with the tracer runs. This is C.I.W. D.P.B. publication number 1293 .

\section{References}

Aber, J.D., and J.M. Melillo, Litter decomposition: Measuring relative contributions of organic matter and nitrogen to forest soils, Can. J. Bot., 58, 416-421, 1980.

Amthor, J.S., The role of maintenance respiration in plant growth, Plant Cell Environ., 7, 561-569, 1984.

Bacastow, R.B., C.D. Keeling, and T.P. Whorf, Seasonal amplitude increase in atmospheric $\mathrm{CO}_{2}$ concentration at Mauna Loa, Hawaii, 1959-1982, J. Geophys. Res., 90(D6), 10,529-10,540, 1985.

Bishop, J.K.B., and W.B. Rossow, Spatial and temporal variability of global surface solar irradiance, J. Geophys. Res., 96(C9), 16,839$16,858,1991$.

Bonan, G.B., Comparison of atmospheric $\mathrm{CO}_{2}$ concentration and metabolic activity in boreal forest ecosystems, Tellus, Ser. B, 44, 173185,1992

Bonan, G., Land-atmosphere $\mathrm{CO}_{2}$ exchange simulated by a land surface process model coupled to an atmospheric general circulation model, J. Geophys. Res., I00(D2), 2817-2831, 1995.

Buchanan, M., and L.D. King, Carbon and phosphorus losses from decomposing crop residues in no-till and conventional till agroecosystems., Agron. J., 85, 631-638, 1993.

Chan, Y.-H., and C.S. Wong, Long-term changes in amplitudes of atmospheric $\mathrm{CO}_{2}$ concentrations at Ocean Station $\mathrm{P}$ and Alert, Canada, Tellus, Ser. B, 42, 330-341, 1990.

Chapin, F.S.I., J.D. McKendrick, and D.A. Johnson, Seasonal changes in carbon fractions in Alaska tundra plants of differing growth form: Implications for herbivory, J. Ecol., 74, 707-731, 1986.

Chapman, W.L., and J.E. Walsh, Recent variations of sea ice and air temperatures in high latitudes, Bull. Am. Meteorol. Soc., 74(1), 33-47, 1993.

Cheng, W., D.C. Coleman, and J.E. Box, Root dynamics, production and distribution in agroecosystems on the Georgia piedmont using minirhizotrons, J. Appl. Ecol., 27, 592-604, 1990.

Conway, T.J., P.P. Tans, L.S. Waterman, K.W. Thoning, D.R. Kitzis, K.A. Masarie, and N. Zhang, Evidence for interannual variability of the carbon cycle from the National Oceanic and Atmospheric Administration/Climate Monitoring and Diagnostics Laboratory global air sampling network, J. Geophys. Res., 99(D11), 22,831$22,855,1994$.

Coley, P.D., J.P. Bryant, and F.S. Chapin, Resource availability and plant antiherbivore defense, Science, 230, 895-899, 1985.

Cuevas, E., and E. Medina, Nutrient dynamics with Amazonian forests, II., Fine root growth, nutrient availability and leaf litter decomposition, Oecologia, 76, 222-235, 1988.

Dai, A., and I.Y. Fung, Can climate variability contribute to the "missing" $\mathrm{CO}_{2}$ sink?, Global Biogeochem. Cycles, 7(3), 599-609, 1993.

DeFries, R.S., and J.R.G. Townshend, NDVI-derived land cover classifications at a global scale, Int. J. Remote Sens., IS(17), 35673586, 1994.

Denning, A.S., Investigations of the transport, sources and sinks of atmospheric $\mathrm{CO}_{2}$ using a general circulation model, $\mathrm{Ph}$. D. Thesis, Colorado State University, Fort Collins, 1994.

Denning, A.S., I.Y. Fung, and D. Randall, Latitudinal gradient of atmospheric $\mathrm{CO}_{2}$ due to seasonal exchange with land biota, Nature, 376, 240-243, 1995.

Detling, J.K., Grasslands and savannas: Regulation of energy flow and nutrient cycling by herbivores, in Concepts of Ecosystem Ecology, edited by L.R. Pomeroy and J.J. Alberts, pp. 131-148, SpringerVerlag, New York, 1988.

Evans, L. T., The natural history of crop yield, Am. Sci., 68, 388-397, 1980.

Eischeid, J.K., H.F. Diaz, R.S. Bradley, and P.D. Jones, A comprehensive precipitation data set for global land areas, Rep. DOE/ER-69017T-HI TRO5I, U. S. Dept. of Energy, Carbon Dioxide Res. Program, Washington, D. C., 1991. 
Fahey, T.J., and J.W. Hughes, Fine root dynamics in a northern hardwood forest ecosystem, Hubbard Brook Experimental Forest, NH, J. Ecol., 82, 533-548, 1994.

Field, C.B., J.T. Randerson, and C.M. Malmström, Ecosystem net primary production: Combining ecology and remote sensing, Remote Sens. Environ., 5I(1), 74-88, 1995.

Francey, R.J., P.P. Tans, C.E. Allison, I.G. Enting, J.W.C. White, and M. Trolier, Changes in oceanic and terrestrial carbon uptake since 1982, Nature, 373, 326-330, 1995.

Friedlingstein, P., I. Fung, E. Holland, H. John, G. Brasseur, D. Erickson, and $\mathrm{D}$. Schimel, On the contribution of the biospheric $\mathrm{CO}_{2}$ fertilization to the missing sink, Global Bingeochem. Cycles, 9(4), 541-556, 1995.

Frost, P.G.H., Organic matter and nutrient dynamics in a broadleafed Africa savanna, in Ecology and Management of the World's Savannas, edited by J.C. Tothill and J.J. Mott, pp. 200-207, Aust. Acad. of Sci., Brisbane, Queensland, Australia, 1984.

Fung, I. Y., K. Prentice, E. Matthews, J. Lerner, and G. Russell, Threedimensional tracer model study of atmospheric $\mathrm{CO}_{2}$ : Response to seasonal exchanges with the terrestrial biosphere, J. Geophys. Res., 88(C2), 1281-1294, 1983.

Fung, I.Y., C.J. Tucker, and K.C. Prentice, Application of advanced very high resolution radiometer vegetation index to study atmosphere-biosphere exchange of $\mathrm{CO}_{2}$,J. Geophys. Res., 92(D3), 2999-3015, 1987

Fung, I.Y., J. John, J. Lerner, E. Matthews, M. Prather, L.P. Steele, and P.J. Fraser, Three-dimensional model synthesis of the global methane cycle, J. Geophys. Res., 96(D7), 13,033-13,065, 1991.

Gallardo, A., and J. Merino, Leaf decomposition in two Mediterranean ecosystems of southwest Spain: Influence of substrate quality, Ecology, 74, 152-161, 1993.

Geng, X., J. Pastor, and B. Dewey, Decay and nitrogen dynamics of litter from disjunct congeneric tree species in old-growth stands in northeastern China and Wisconsin, Can. J. Bot., 71, 693-699, 1993.

Gholz, H.L., C.S. Perry, J.W.P. Cropper, and L.C. Hendry, Litterfall, decomposition and nitrogen and phosphorous dynamics in a chronosequence of Slash Pine (Pinus elliotii) plantations, For. Sci., $31,463-478,1985$.

Gillette, D.A., and E.O. Box, Modeling seasonal changes of atmospheric carbon dioxide and carbon 13, J. Geophys. Res., 91(D4), 5287-5304, 1986.

Goldewijk, K.K., J.G. Van Minnen, G.J.J. Kreileman, M. Vloedbeld, and R. Leemans, Simulating the carbon flux between the terrestrial environment and the atmosphere, Water Air Soil Pollut., 76, 199-230, 1994.

Goulden, M.L., J.W. Munger, S.M. Fan, B.C. Daube, and S.C. Wofsy, Exchange of carbon dioxide by a deciduous forest: Response to interannual climate variability, Science, $271,1576-1578,1996$.

Goward, S.N., B. Markham, E.G. Dye, W. Dulaney, and J. Yang, Normalized difference vegetation index. Measurements from the advanced very high resolution radiometer, Remote Sens. Environ., 35(2-3), 257-278, 1991.

Gower, S.T., and Y. Son, Differences in soil and leaf litterfall nitrogen dynamics for five forest plantations, Soil. Sci. Soc. Am. J., 56, 1959$1966,1992$.

Hall, C.A.S., C.A. Ekdahl, and D.E. Wartenberg, A fifteen-year record of biotic metabolism in the Northern Hemisphere, Nature, 255, 136138, 1975.

Hansen, J., and S. Lebedeff, Global trends of surface air temperature, J. Geophys. Res., 92(D11), 13,345-13,372, 1987.

Harmon, M.E., et. al., Ecology of coarse woody debris in temperate ecosystems, Adv. Ecol. Res., 15, 133-302, 1986.

Hart, S., and M.K. Firestone, Decomposition and nutrient dynamics of ponderosa pine needles in a Mediterranean-type climate, Can. J. For. Res., 22, 306-314, 1992.

Heimann, M., and C.D. Keeling, A three-dimensional model of atmospheric $\mathrm{CO}_{2}$ transport based on observed winds, 2., Model description and simulated tracer experiments, in Aspects of Climate Variability in the Pacific and the Western Americas, Geophys. Monogr. Ser., vol. 55, edited by D.H. Peterson, pp. 237-275, AGU, Washington, D.C., 1989.

Hendrick, R.L., and K.S. Pregitzer, The dynamics of fine root length, biomass and nitrogen content in two northern hardwood ecosystems, Can. J. For. Res., 23, 2507-2520, 1993a.
Hendrick, R.L., and K.S. Pregitzer, Patterns of root mortality in two sugar maple forests, Nature, 361, 59-61, 1993b.

Houghton, R.A., Land-use change and the carbon cycle, Global Change Biol., 1, 275-287, 1995.

Huck, M.G., G. Hoogenboom, and C.M. Peterson, Soybean root senescence under drought stress, in Minirhizotron Observation Tubes: Methods and Applications for Measuring Rhizosphere Dynamics, edited by H.M. Taylor, pp. 109-121, Am. Soc. Agron., Madison, Wis., 1987.

Jenkinson, D.S., D.E. Adams, and A. Wild, Model estimates of $\mathrm{CO}_{2}$ emissions from soil in response to global warming, Nature, 351, 304306, 1991.

Keeling, C.D., Global observations of atmospheric $\mathrm{CO}_{2}$, in The Global Carbon Cycle, edited by M. Heimann, pp. 1-21, Springer-Verlag, New York, 1993.

Keeling, C.D., J.F.S. Chin, and T.P. Whorf, Increased activity of northern vegetation inferred from atmospheric $\mathrm{CO}_{2}$ measurements, Nature, 382, 146-149, 1996.

Kirschbaum, M.U.F., The temperature dependence of soil organic matter and the effects of global warming on soil organic $\mathrm{C}$ storage, Soil Biol. Biochem., 27(6), 753-760, 1995.

Knorr, W., and M. Heimann, Impact of drought stress and other factors on seasonal biosphere $\mathrm{CO}_{2}$ exchange studied through an atmospheric tracer transport model, Tellus, Ser. B, 47, 471-489, 1995.

Kohlmaier, G.H., E.O. Sire, A. Janecek, C.D. Keeling, S.C. Piper, and R. Revelle, Modeling the seasonal contribution of a $\mathrm{CO}_{2}$ fertilization effect of the terrestrial vegetation to the amplitude increase in atmospheric $\mathrm{CO}_{2}$ at Mauna Loa observatory., Tellus, Ser. B, 41, 487$510,1989$.

LaMotte, M., and F. Bourliere, Energy flow and nutrient cycling in tropical savannas, in Ecosystems of the World. Tropical savannas, vol. 13, edited by F. Bourliere, pp. 583-603, Elsevier Sci., New York, 1983.

Landsberg, J., and C. Ohmart, Levels of insect defoliation in forests: Patterns and concepts, Trends Ecol. Evol., 4(4), 96-100, 1989.

Leemans, R., and W.P. Cramer, The IIASA database for mean monthly values of temperature, precipitation and cloudiness of a global terrestrial grid. Rep. WP-41, 60 pp., Int. Inst. Appl. Sys. Anal., Laxenburg, Austria, 1990.

Los, S.O., C.O. Justice, and C.J. Tucker, A global 1xI NDVI data set for climate studies derived from GIMMS continental NDVI data, Int. $J$. Remote Sens, 15(17), 3493-3518, 1994.

Matthews, E., Global vegetation and land use: New high-resolution data bases for climate studies, J. Clim. Appl. Meteorol., 22, 474-487, 1983.

McNaughton, S.J., M. Oesterheld, D.A. Frank, and K.J. Williams, Ecosystem-level patterns of primary production and herbivory in terrestrial habitats, Nature, 341, 142-144, 1989.

McNaughton, S.J., M. Oesterheld, D.A. Frank, and K.J. Williams, Primary and secondary production in terrestrial ecosystems, in Comparative Analyses of Ecosystems, edited by J. Cole, G. Lovett, and S. Findlay, pp. 120-139, Springer-Verlag, New York, 1991.

Medina, E., and E. Cuevas, The patterns of nutrient accumulation and release in Amazonia forests of the upper Rio Negro basin, in Mineral Nutrients in Tropical Forests and Savanna Ecosystems, edited by J. Proctor, pp. 217-240, Blackwell Sci., Cambridge, Mass., 1989.

Melillo, J.M., J.D. Aber, and J.F. Muratore, Nitrogen and lignin controls of hardwood leaf litter decomposition dynamics, Ecology, 63, 621626,1982

Morris, J.W., J.J. Bezvidenhout, and P.R. Furniss, Litter decomposition, in Ecology of Tropical Savannas, edited by B.J. Huntley and B.H. Walker, Springer-Verlag, pp. 535-553, New York, 1982.

Oechel, W.C., S. Cowles, N. Grulke, S.J. Hastings, B. Lawrence, T, Prudhomme, G. Riechers, B. Strain, D. Tissue, and G. Vourlitis, Transient nature of $\mathrm{CO}_{2}$ fertilization in Arctic tundra, Nature, 371, 500-502, 1994.

Palm, C.A., and P.A. Sanchez, Decomposition and nutrient release patterns of the leaves of three tropical legumes, Biotropica, 22(4), 330-338, 1990.

Parmelee, R.W., M.H. Beare, and J.M. Blair, Decomposition and nitrogen dynamics of surface weed residues in no-tillage agroecosystems under drought conditions: influence of resource quality on the decomposer community, Soil Biol. Biochem., 21(1), 97. 103, 1989. 
Parton, W.J., J.W.B. Stewart, and C.V. Cole, Dynamics of C, N, P and S in grassland soils: A model, Biogeochemistry, 5, 109-131, 1988.

Parton, W.J., et al., Observations and modeling of biomass and soil organic matter dynamics for the grassland biome worldwide, Global Biogeochem. Cycles, 7(4), 785-809, 1993.

Potter, C.S., J.T. Randerson, C.B. Field, P.A. Matson, P.M. Vitousek, H.A. Mooney, and S.A. Klooster, Terrestrial ecosystem production: A process model based on global satellite and surface data, Global Biogeochem. Cycles, 7(4), 811-841, 1993.

Raich, J.W., and C.S. Potter, Global patterns of carbon dioxide emissions from soils, Global Biogeochem. Cycles, 9(1), 23-36, 1995.

Raich, J.W., and W.H. Schlesinger, The global carbon dioxide flux in soil respiration and its relationship to climate, Tellus, Ser. $B, 44,81$ 99, 1992.

Raich, J.W., E.B. Rastetter, J.M. Melillo, D.W. Kicklighter, P.A. Steudler, and J. Peterson, Potential net primary productivity in South America: Application of a global model, Ecol. Appl.,1(4), 399-429, 1991.

Randall, D.A.,et al.,, A revised land surface parameterization (SiB2) for GCMs, 3, The greening of the Colorado State University general circulation model, J. Clim., 9(4), 738-763, 1996.

Running, S.W., and E.R. Hunt, Generalization of a forest ecosystem process model for other biomes, BIOME-BGC, and an application for global-scale models, in Scaling Physiological Processes: Leaf to Globe, edited by J.R. Ehleringer and C.B. Field, Pp. 141-158, Academic, San Diego, Calif., 1993.

Schaefer, D., Y. Stienberger, and W.G. Whitford, The failure of nitrogen and lignin control of decomposition in a North American desert, Oecologia, 65, 382-386, 1985.

Schimel, D.S., B.H. Braswell, E.A. Holland, R. Mckeown, D.S. Ojima, T.H. Painter, W.J. Parton, and A.R. Townsend, Climatic, edaphic, and biotic controls over storage and turnover of carbon in soils, Global Biogeochem. Cycles, 8(3), 279-293, 1994.

Schlesinger, W.H., Decomposition of chapparal shrub foliage, Ecology, 66, 1353-1359, 1985.

Scott, D.A., J. Proctor, and J. Thompson, Ecological studies on a lowland evergreen rain forest on Maraca Island, Roraima, Brazil., II., Litter and nutrient cycling, J. Ecol., 80, 705-717, 1992.

Seastedt, T.R., Mass, nitrogen, and phosphorus dynamics in foliage and root detritus of tallgrass prairie, Ecology, 69, 59-65, 1988.

Seastedt, T.R., W.W. Parton, and D.S. Ojima, Mass loss and nitrogen dynamics of decaying litter of grassland: The apparent low nitrogen immobilization potential of root detritus, Can. J. Bot., 70, 384-391, 1992.

Sellers, P.J., C.J. Tucker, G.J. Collatz, S.O. Los, C.O. Justice, D.A. Dazlich, and D.A. Randall, A global $1^{\circ}$ by $1^{\circ}$ NDVI data set for climate studies., 2., The generation of global fields of terrestrial biophysical parameters from the NDVI, Int. J. Remote Sens., 15(7), 3519-3545, 1994.

Smil, V., Nitrogen and phosphorus, in The Earth as Transformed by Human Action, edited by B.L. Turner, W.C. Clark, R.W. Kates, J.F. Richards, J.T. Mathews, and W.B. Meyer, pp. 423-436, Cambridge Univ. Press, New York, 1990.

Stienberger, D., and W.G. Whitford, Decomposition processes in Negrev ecosystems, Oecologia, 75, 61-66, 1988.

Stump, L.M., and D. Binkley, Relationships between leaf litter quality and nitrogen availability in Rocky Mountain forests, Can. J. For. Res., 23, 492-502, 1993.

Tans, P.P., I.Y. Fung, and T. Takahashi, Observation constraints on the global atmospheric $\mathrm{CO}_{2}$ budget, Science, 247, 1431-1438, 1990.

Taylor, B.R., C.E. Prescott, W.J.F. Parsons, and D. Parkinson, Substrate control of litter decomposition in four Rocky Mountain coniferous forests, Can. J. Bot., 69, 2242-2250, 1991.

Townsend, A.R., B.H. Braswell, E.A. Holland, and J.E. Penner, Spatial and temporal patterns in terrestrial carbon storage due to deposition of anthropogenic nitrogen, Ecological Applications, In press, 1996.

van Hoven, W. and E.A. Boomker, Digestion, in Bioenergetics of Wild Herbivores, edited by R.J. Hudson and R.G. White, pp. 103-120, CRC Press, Inc., Boca Raton, Fl., 1985.

Vitousek, P.M., Litterfall, nutrient cycling and nutrient limitation in tropical forests, Ecology, 65, 285-298, 1984.

Vitousek, P. M., P. R. Ehrlich, A. E. Ehrlich, and P. A. Matson, Human appropriation of the products of photosynthesis, Bioscience, 36, 368373, 1986.

Wagger, M.G., Time of desiccation effects on plant composition and subsequent nitrogen release from several winter annual cover crops, Agron. J., 81, 236-241, 1989.

Zobler, L.A., World soil file for global climate modeling, NASA Tech. Memo., 87802, 32 pp., 1986.

C. B. Field, C. M. Malmstrom, J. T. Randerson, and M. V. Thompson, Carnegie Institution of Washington, Department of Plant Biology, 290 Panama Street, Stanford, Ca. 94305. (e-mail: chris@jasper.stanford.edu; carolyn@jasper.stanford.edu; orcinus@jasper.stanford.edu; matt@arbutus.stanford.edu)

I. Y. Fung, School of Earth and Ocean Sciences, University of Victoria, P.O. Box 1700, Victoria, British Columbia, Canada V8W 2 Y2. (e-mail: inez@garryoak.seaoar.uvic.ca)

(Received December 13, 1995; revised June 17, 1996; accepted June 24, 1996.) 